\title{
ANONIM ŞİRKETLERİN KENDİ PAYLARINI İKTİSABININ HUKUKİ SONUÇLARI
}

\author{
LEGAL CONSEQUENCES OF JOINT STOCK COMPANIES' ACQUISITION OF THEIR \\ OWN SHARES
}

Murat Can ATAKAN* $m$ (iD

Makale Bilgi

Gönderi: 29/03/2021

Kabul : 30/05/2021

\section{Anahtar Kelimeler}

Kendi Payın İktisap, Yönetim Hakkının

Donmasl,

Temsil Hakkının

Donmasl,

Malvarliksal Hakkının

Donmast,

Kaçış Klozu

\section{Article Info}

Received: 29/03/2021

Accepted: 30/05/2021

\section{Keywords}

Acquisition of Own

Shares,

Freezing of Management

Right,

Freezing of

Representation Right,

Freezing of Assets,

Escape Clause
Özet

https://dai.org/10.21492/inuhfd.904845 do

Pay sahipleri kural olarak kendi paylarını serbestçe devredebilse de devralacak kişinin anonim şirketin bizatihi kendisinin olması, birtakım sorunları ve sınırlamaları da beraberinde getirmektedir. Bir anonim şirketin kendi paylarını iktisabı, kanun koyucu tarafindan istisnai olarak kabul edilmiș ve söz konusu iktisap hem sınırlamalara tabi tutulmıș hem de söz konusu payların -birtakım şartlar altında- elden çıkarılması zorunlu hale getirilmiştir. Şirketin kendi paylarını iktisabına ilişkin bu sınır ve şartlar, kanunda nispeten açıkça düzenlenmekle beraber, bunlara aykırılık durumunda işlemin ve iktisap edilen payların akıbetinin ne olacağı hususunda bir düzenleme bulunmamaktadır. Çalışmamızda öncelikle şirketin kendi paylarını iktisabının koşulları ve paya bağlı hakların kullanılamaması genel olarak açıklanmış, ardından da kanuna uygun ve kanuna aykırı olarak ikstisap edilen payların durumu ayrı ayrı izah edilmeye çalışılmıştır. Bu bağlamda payların elden çıkarılması zorunluluğu gerek TTK md. 379 gerekse TTK md. 382 ve 383 hükümlerine uygun olarak iktisap edilen paylar bakımından incelenmiş, ardından da payların yok edilmesi (itfa) zorunluluğu değerlendirilmeye çalışılmıștır. Ayrıca TTK'nın 493.maddesinde düzenlenen "kaçış klozu" bağlamında, şirketin kendi paylarını iktisabı incelenmiş ve bu bağlamda şirketin birtakım sınırlamalarla bağlı olup olmadığı değerlendirilerek kendi kanaatlerimiz aktarılmaya çalışılmıştır. Son olarak şirketin kendi payını iktisap etmesi halinde, yedek akçe ayırma zorunluluğu ve iktisap edilen payların bilançodaki durumu değerlendirilmiş ve sonuç kısmında konuya ilişkin kanaatlerimize yer verilmiştir.

\begin{abstract}
Shareholders could transfer their shares freely as a rule; however, some problems and restrictions come within where the transferee is company itself. The acquisition of its own shares by a joint stock company has been accepted as an exception by lawmaker, and that acquisition has been subject to percentage limitations and the transfer of this shares -under certain conditions- has been made obligatory. These limits and conditions are regulated comparatively clearly in the law; however, there is no such regulation on the outcome of the transaction of transfer and the acquired shares in case of violation of these rules. In our study, it is tried to be explained respectively the conditions of the company's acquisition of its shares and the incapacity to use the rights linked with shares, and then the status of the shares acquired both legal and illegal. In this context it is tried to be construed the obligation of transfer of the shares acquired in accordance with the articles of both TCC 382 and 383, and then the obligation to extinguish. Besides, the company's acquisition of its own shares examined within the context of the "escape clause" regulated in Article 493 of the TCC, and accordingly it is evaluated that whether the company was bound by certain restrictions in the light of the opinions in the comparative law and doctrine, and our opinions tried to be conveyed. Finally, it is evaluated the obligation to set aside reserve fund and the status of the acquired shares in the balance sheet in case the company acquires its own share, and our opinions on the subject were tried to be conveyed in the conclusion section.
\end{abstract}

* Dr. Öğr. Üyesi, Altınbaş Üniversitesi, Hukuk Fakültesi, Ticaret Hukuku Anabilim Dall. 


\section{EXTENDED SUMMARY}

The acquisition of its own shares by joint stock companies has been accepted as an exception rule by lawmaker. Thus, lawmaker enacted important restrictions and rules to this important situation. Violation of these rules brought by the lawmaker brings important sanctions. The most important of these sanctions is the incapacity to use the rights linked to the share. Because the joint stock company will not have the capacity to use the rights arising from its own shares acquired, as long as the shares belong to the company. This situation will cause the freezing of the rights regarding the right to representation, the right to assets and the protective facilities as well as the rights regarding the management.

The acquisition of its own shares by the company will bring the obligation to transfer the shares. The reason why there is no obligation to transfer of shares is the purpose of these shares is not stated in law, as stated in the justification of the law within the scope of TCC 379. Although there is no obligation in this regard, in case the shares are transferred by the company, the transfer of the shares must be carried out in accordance with the principle of equal treatment and the prohibition of shareholders borrowing from the company. Otherwise, the decision of the board of directors must be regarded as void in accordance with the provisions of Article 391 of the TTK. Any acquisition carried out in accordance with the Article 379 of the TCC should not be considered as a transaction in compliance with the law and eliminating the responsibility. Because, during the execution of transactions, the board of directors has responsibilities within the framework of the Articles 369 and 553 of the TCC due to culpable transactions.

There is no obligation to transfer of shares that do not exceed $10 \%$ in terms of acquisitions realized within the framework of the Article 382 and 383 of the TCC; however, in case of end of force majeure the shares will have to be transferred as stated in the justification of Article 384 of the TCC. In this case, only the shares exceeding $10 \%$ will be transferred.

In cases where the shares are acquired contrary to law, there is an illegal transfer. In this regard the followings are illegal acquisition; absence of authorization of general board, arrearage of the price of share, covering the amount from free reserve funds or exceeding the $10 \%$ limit. Likewise, even though there is no imminent and serious risk of loss, it will be violation of the law for the board of directors to acquire the company shares and the transactions in question are invalid. As we mentioned in our study, what the invalidity will be here is controversial in the doctrine, but in our opinion, evaluating the transaction as "void" would be the ideal solution.

The first transaction to be made in the event that the joint stock company exceeds the $10 \%$ limit while acquiring its own shares, is the transfer of the share, but the shares not transferred within the scope of Article 384 and 385 TCC will be abated by reducing the capital. In this case, as stated by the legislator, the shares should be abated "immediately". While the capital of the company is reduced due to the extinguish of shares, the minimum capital amounts specified in the law should not be reduced. If such a situation is encountered, a capital increase will be made immediately after the extinguish and an increase will be provided up to the minimum amount of capital. If new shares will be issued in an amount to meet the reduced portion and the prices of these shares will be paid in full, there will be no need to change the articles of association.

In accordance with the Article 493/I of the TCC, a consensus could not be reached in the doctrine as to whether there will be a restriction if the company acquires its own shares by using the "escape clause". At this point, our opinion is that the $10 \%$ limit specified in Article 379 of the TCC is also applied in the escape clause. Because, advocating the contrary will bring along many problems, as we have emphasized in our study.

The joint stock company must also reserve an amount of reserve funds that meet the acquisition value. This matter is a necessity in accordance with the Article 520/1 of the TCC; however, this is the case only in cases where the company has actively acquired its own shares. The dividends will have to be refunded in accordance with the Article 512 of the TCC, if a dividend distribution is made without allocating the reserves in question.

Finally, in the event that the company acquires its own shares, there is no regulation in the Turkish Commercial Code regarding the requirement to show the acquired shares on the balance sheet. However, in accordance with the Article 74 of the TCC et al, since all matters regarding the company's assets will be transferred to the balance sheet, the acquired shares and the reserves allocated in return should be included in the liabilities part of the balance sheet. 


\section{GİRIŞ}

Bir anonim şirketin payı kural olarak serbestçe devredilebilmektedir; ancak devralacak kişi bakımından bir sınırlama söz konusudur. Bir anonim şirket kendi paylarına ancak kanunda belirtilen şartlara, sinırlara ve usule uygun olmak koşuluyla sahip olabilmektedir. TTK md. 379/1 düzenlemesiyle bir şirketin kendi paylarını ${ }^{1}$ iktisabıyla ilgili oransal bir sınırlama getirilmiş ve esas veya çıkarılmış sermayenin onda birini aşan veya bir işlem sonrasında aşacak olan miktarda payı, ivazlı olarak iktisap ve rehin olarak kabul edemeyeceği hüküm altına alınmıştır. Bir başka deyişle anonim şirket, söz konusu sınırlar içinde, ortağı konumundaki pay sahibinden belirli bir bedel karşılığında paylarını satın alabilmektedir.

Şirketin kendi paylarını iktisabı genel kurulun vereceği yetkiyle yönetim kurulu tarafından gerçekleştirilebilir ve söz konusu yetki en fazla beş yıllık bir süre için verebilir. İktisap edilecek payların toplam itibari değerleriyle bu paylara ödenecek bedellerin limitleri de kararda gösterilmelidir. Ayrıca genel kurulun izin kararında öngörülen şartların gerçekleştiğinin de yönetim kurulu tarafından belirtilmesi gerekmektedir ${ }^{2}$. Bahse konu satın alma işlemi bir devren kazanma biçimidir. Anonim şirkete ait payın, şirket tarafindan aslen kazanılması ise, TTK md. 388 hükmü çerçevesinde kanun koyucu tarafından yasaklanmıştır³.

Anonim şirketin kendi paylarını iktisap edememesine ilişkin düzenlemelerin temelinde, sermayenin korunması ve yönetim kurulu ile genel kurul arasındaki yetki sınırlamaları yer almaktadır ${ }^{4}$. Ayrıca genel kurulun devredilemez görev ve yetkilerini korumak ve yönetim kurulunun şirketin pay sahipliği yapısına müdahale etmesini engellemek de hükmün amaçlarındandır ${ }^{5}$. Şirketin kendi paylarını iktisabının, şirketin malvarlığının zayıflamasına sebep olacağı da ileri sürülmektedir ${ }^{6}$. Bu durum hem ortaklık alacaklılarının haklarına halel getirmekte hem de pay sahiplerinin sermaye olarak şirkete verdiklerini geri isteyemeyecekleri kuralını (TTK 480/3) ihlal etmektedir?

Kısıtlamanın amaçlarından bir diğeri ise düşük miktarlarda paya sahip kişilerin, şirkette oluşan kontrol boşluğundan faydalanarak, yönetimi ele geçirmesinin engellenmesidir. Zira anonim şirketin kendi paylarını devralması, bahse konu paylara özgülenen oy haklarının kullanılamamasına ve dolayısıyla bu payların oy hesabında dikkate alınamamasına sebep olacaktır. Kullanılmayan oylar ise karar nisaplarını değiştirecek ve genel kurulda daha düşük oylarla kararlar alınabilecektir. Bu yolla düşük miktarda paya sahip bazı kişilerin anonim şirketi kontrol edebilmesinin de önü açılmış olacaktır ${ }^{8}$.

Halka açık bir anonim şirketin düşen hisse senetlerini satın alıp, yapay bir değer artışı meydana getirmesinin engellenmeye çalışılması da pay iktisabı kısıtlamalarının amaçlarından birisidir. Zira yönetim kurulunun, işlerin yolunda gitmediği dönemlerde şirketin parasılyla hisse senedi alıp, yatırımcıları zarara uğratması söz konusu olabilmektedir ${ }^{9}$. Bu durum özellikle borsada işlem gören şirketler bakımından bir yapay artışa sebep olacağı için, kanımızca manipülasyon kapsamında da değerlendirilebilecektir.

Anonim şirketin kendi paylarını iktisabını engelleyen düzenlemelerin temelinde yatan bir diğer sebep ise, pay sahiplerinin eşit işleme tabi tutulması ilkesidir. Kural olarak aynı şartlar altındaki pay sahiplerinin aynı işleme tabi tutulması gerekmektedir. Bu sayede hiçbir pay sahibi, diğer pay sahiplerinden daha kötü şartlar altında bir işleme tabi tutulamayacaktır ${ }^{10}$. Söz konusu ilke gereğince,

\footnotetext{
${ }^{1}$ Söz konusu kavram, anonim şirketin kendi sermayesinin bir bölümünü oluşturan ve anonim şirketin bizatihi kendisinin sahip olmadığı, üçüncü kişilerin elinde bulunan paylardır. ÇELİKTAŞ, İlyas: Anonim Ortaklığın Kendi Paylarını İktisabı, 1.Bas1, Arikan, Ankara 2006, s.31.

${ }^{2}$ PULAŞLI Hasan: Şirketler Hukuku Genel Esaslar, 6.Bası, Adalet, Ankara 2020, § 27, N.3.

${ }^{3}$ SEVI, Ali Murat: Anonim Ortaklıkta Payın Devri, 4.Bası, Seçkin, Ankara 2018, s.69. Anonim şirketin, bedeli tamamen ödenmiş olan kendi paylarını karşılıksız olarak devralmasıysa, herhangi bir kısıtlamaya tabi değildir. Bu durumun tek istisnası, elden çıkarma yükümlülüğüdür.

${ }^{4}$ HÜFFER, Uwe: Aktiengesetz, 14.Bas1, Beck 2020, § 71, N.1.

5 ÖZDAMAR, Mehmet: Anonim Ortaklıkların Kendi Paylarını İktisap Etmesi (TTK md. 329), 1.Bası, Yetkin, Ankara 2005, s.217; TÜRK, Ahmet: Anonim Ortaklığın Kendi Paylarını Edinmesi, 1.Bası, Adalet, Ankara 2016, s.293 vd; ÇAPA, Mehmet Sadık: Anonim ve Limited Şirketlerin Kendi Paylarını İktisap Etmesi, 1.Bas1, On İki Levha, İstanbul 2013, s.132. ${ }^{6}$ FORSTMOSER, Peter/MEIER-HAYOZ, Arthur/NOBEL, Peter: Schweizerisches Aktienrecht, 1.Bası, Stämpfli 1996, § 50, N.131.

${ }^{7}$ TEKİL, Fehiman: Anonim Şirketler Hukuku, 1.Bas1, İstanbul 1993, s.277.

${ }^{8}$ SEVİ, Pay Devri, s.74.

${ }^{9}$ ANSAY, Tuğrul: Anonim Şirketler Hukuku, 6.Bası, İstanbul 1982, s.267; BARTU, Nihat: “Anonim Şirketlerin Kendi Hisse Senetlerini Satın Almaları” İstanbul Barosu Dergisi, 8, 1947, s.348.

${ }^{10}$ NOMER, Füsun: “Anonim Ortaklıkta Eşit Davranma (Eşit İşlem) İlkesi” in Prof. Dr. Oğuz İmregün'e Armağan, İstanbul 1998, s.469; YILDIZ, Şükrü: Anonim Ortaklıkta Pay Sahipleri Açısından Eşit İşlem İlkesi, 1.Bası, Seçkin, Ankara 2004, s.68 ve 47 dn. 100 'de yer alan yazarlar.
} 
pay sahiplerinden bir ya da birkaçının payının, şirket tarafından iktisabı engellenecektir ${ }^{11}$. Eşit işlem ilkesine aykırılık halinde, ilgili yönetim kurulu kararı batıl olacaktır ${ }^{12}$. Devralmanın dayanağı olan yönetim kurulu kararının batıl olması ise -mülkiyetin devrinin illi bir işlem olup olmadığı yönündeki tartışmalara girmeksizin- kanun koyucunun TTK md. 357 ve md. 391 hükümleri ile ortaya koyduğu amaca da uygun şekilde, devir işleminin de geçersizliği sonucunu doğuracaktır ${ }^{13}$.

Aşağıdaki bölümde, anonim şirketlerin kendi paylarını iktisabının hukuki sonuçları ayrı ayrı ele alınmış ve detaylıca incelenmeye çalışılmıştır.

\section{PAYA BAĞLI HAKLARIN KULLANILAMAMASI}

Anonim şirket, bedelsiz edinilen paylar haricinde, iktisap ettiği kendi paylarından doğan hakları kullanamayacaktır. Şirketin sahip olduğu kendi paylarından doğan pay sahipliği hakları ise TTK md. 389 hükmü gereğince, payların şirketin uhdesinde bulunduğu süre zarfinda donacaktır ${ }^{14}$. Payın kanuna uygun veya aykırı olarak iktisap edilip edilmemesinin de bir önemi bulunmamaktadır. Şirket herhangi bir şekilde kendi paylarını edinirse paya bağlı haklar donacak, söz konusu payların elden çıkarılması halindeyse, bu haklar tekrar canlanacaktır ${ }^{15}$. Bu yüzden anonim şirketin kendi paylarını iktisap etmesinin, kendi kendinin ortağı olacağı manasına gelmediğini, burada yalnızca payların "emanetçisi" konumunda bulunduğunu ifade eden yazarlar da mevcuttur ${ }^{16}$. Burada en önemli amaç, şirket organları arasındaki yetki paylaşımının korunmasıdır ${ }^{17}$.

Anonim şirketin TTK 382.maddede yer alan istisnalara dayanarak kendi paylarını iktisap etmesi durumunda, her ne kadar 379.maddede yer alan şartlardan muaf olsa da iktisap dolayısıyla payların bürüneceği hukuki durumundan muafiyet söz konusu olamayacağından, bu paylara ilişkin pay sahipliği hakları kullanılamayacaktır ${ }^{18}$.

Şirket hesabına ancak üçüncü kişi adına iktisap edilen payların da donacağı kabul edilmektedir ${ }^{19}$. Zira TTK 389.maddede açık bir hüküm bulunmasa da TTK 380/2 hükmü gereğince şirketin üçüncü kişiyle yaptığı ve bu kişinin şirketin hesabına aldığı payların, bizzat şirketin alması halinde TTK 379.maddeye aykırı kabul edilecekse, batıl olacağı hüküm altına alınmıştır.

\section{A. Yönetsel Hakların Donması}

Anonim şirket yönetim kurulu tarafindan yönetilse de bu süreç içerisinde pay sahiplerinin genel kurula katılması, oy kullanması, görüs bildirmesi, bilgi alma ve denetim haklarını kullanması, genel kurulun ve alınan kararların hükümsüzlüğüne ilişkin davalar açması yahut azınlık pay sahipleri ile imtiyazlı pay sahiplerinin özel durumları sebebiyle sahip oldukları hakları kullanmaları, şirket yönetimine dolaylı olarak müdahale anlamına gelmektedir ${ }^{20}$.

Şirket yönetiminde önemli rol oynayan tüm bu haklar (bedelsiz pay alma haricindeki donan tüm haklar) arasında belki de en önemlileri, genel kurula katılma ve oy kullanma hakkıdır. Bu nedenledir ki, şirketin iktisap ettiği kendi payları için oy ve oya bağlı hakların kullanması mümkün değildir ${ }^{21}$. Söz konusu hakların kullanılamaması hali, gerek kanuna uygun olarak iktisap edilen paylar gerekse TTK

${ }^{11}$ ANSAY, s.267. Paylardan bazılarının gerçek değeri üzerinde bir bedelle satın alınmasııın da eşit işlem ilkesine aykırı olacağı yönünde bkz.: ÖZDAMAR, s.82; ÇELIKTAŞ, s.141.

${ }^{12}$ ÇELIKTAŞ, s.220-221; YILMAZ, Asuman: "Alman Hukuku'nda Anonim Ortaklığın Kendi Paylarını Devralması ve "KonTraG" ile Getirilen Değişiklikler”, İstanbul Üniversitesi Hukuk Fakültesi Mecmuası, LXIII (1-2), 2005, s.265; SEVİ, Pay Devri, s.73. Yazar bu sonuca TTK 391.md hükmünden ulaşmaktadır.

13 ÖZDAMAR, s.229; ÇELIKKTAŞ, s.223; SEVİ, Pay Devri, s.73. Mehaz Alman Hukuku'nda ise soyutluk ilkesi (Abstraktionsprinzip) kabul edildiği için, borçlandırıcı işlemdeki geçersizliğin tasarruf işlemini etkilemesi mümkün değildir (AktG § 71). Tarihsel süreçte yaşanan değişimler hakkında detaylı bilgi için bkz.: AYDIN, Alihan: Anonim Ortaklığın Kendi Paylarını Edinmesi, 1.Bası, Arıkan, Ankara 2008, s.110 vd. ve s.256.

${ }^{14}$ TEOMAN, Ömer: "Şirketçe Devralınan Payların Umumi Heyette Temsili Caiz Değildir Kuralının (TK. m. 329, f. 3, c.

2) Anlamı", in Otuz Yıl Ticaret Hukuku - Tüm Makalelerim - C.I:1971-1982, 1.Bas1, İstanbul 2001, s.263-264;

TEKINALP, Ünal: Yeni Anonim ve Limited Ortaklıklar Hukuku ile Tek Kişi Ortaklığının Esasları, 2.Bası, Vedat, İstanbul 2012, s.377.

${ }^{15}$ ÇAPA, s.133; AYOĞLU, Tolga: “Anonim Ortaklıkların Kendi Paylarını İktisap Etmeleri ve Karşılıklı Katılmalar Meselesi” in İsviçre Borçlar Kanunu'nun İktibasının 80. Yılında İsviçre Borçlar Hukuku'nun Türk Ticaret Hukuku'na Etkileri, 1.Bas1, Vedat, İstanbul 2009, s.531; TÜRK, s.294; ÖZDAMAR, s.218-219.

${ }^{16}$ ÇELİKTAŞ, s.147; GÖKÇE, Ziya: "Şirket Hisselerinin Devir Engelleri ve Hukuki Sonuçları", Türkiye Noterler Birliği Hukuk Dergisi, 106, 2000, s.45.

17 YILMAZ, Asuman, “Avrupa Birliği Hukuku’nda Anonim Ortaklığın Kendi Paylarını Devralması” in Prof.Dr.Ergun Özsunay’a Armağan, 1.Bas1, Vedat, İstanbul 2004, s.35.

${ }^{18}$ PULAŞLI, Hasan: 6102 Sayılı Türk Ticaret Kanununa Göre Şirketler Hukuku Şerhi, Cilt II, 1.Bası, Adalet, Ankara 2011, s.1238.

19 TÜRK, s.295.

${ }^{20}$ TEOMAN, Şirketçe Devralınan Paylar, s.262.

${ }^{21}$ ÖZDAMAR, s.218; AYDIN, s.271. 
379 vd hükümlerine aykırı olarak iktisap edilen paylar bakımından uygulanmaktadır 22 .

Kanun koyucu şirketler topluluğu içerisinde yer alan bağl1 şirketin iktisap ettiği hakim şirket paylarınınsa, hakim şirketin genel kurul toplantı nisaplarında hesaba katılmayacağını ve söz konusu paylara ilişkin oy hakkı ile buna bağlı hakların donacağını, TTK md. 389 hükmüyle açıkça ifade etmiştiri ${ }^{23}$. Bir başka deyişle oy ve oya bağlı olan; genel kurula katılma, öneride bulunma, iptal davası açma, bilgi alma ve azınlık hakları da donacaktır ${ }^{24}$.

Donan paya bağlı hakların tekrar canlanabilmesi için şirketin söz konusu payları elinden çıkarması gerekmektedir. Nezaman ki şirket payları elinden çıkarır, devirle birlikte payların yeni sahibinin paya bağlı hakları da o anda doğacaktır ${ }^{25}$. Ancak oy hakkının donmasına ilişkin hükümleri "dolanabilmek" için payları üçüncü kişilere devretmek ve bu yolla oy haklarını kullanmak, TTK md. 433 hükmüyle yasaklanmıştır. Bu yasağa rağmen oyların kullanılması durumunda, pay sahiplerinin ilk olarak TTK md. 433/2 hükmü gereğince, itirazda bulunma ve bu itirazını tutanağa geçirtme hakk1 bulunmaktadır ${ }^{26}$. Bunun yanısıra ilgili genel kurul kararının geçersizliği talebinde de bulunulabilecektir. Bir görüsşe göre, -genellikle- nisaplar sağlanmadan karar alındığı için genel kurul kararı yoklukla maluldür ${ }^{27}$. Bir diğer görüsse göreyse, anonim şirketin iktisap ettiği paylarla genel kurula katılması, TTK 446/1-b hükmü gereğince genel kurul kararının iptal edilebilirliği sonucunu doğuracaktır ${ }^{28}$.

Genel kurula katılma hakkının donması ile yönetim kurulunun genel kuruldaki etkinliğinin arttırılmasının ve yönetim kurulu ile ona yakın pay sahiplerinin yahut hakim şirketin menfaatine kararlar alınmasının engellenmesi amaçlanmış ve pay sahiplerinin iradesinin genel kurula uygun ve doğru şekilde yansıması arzu edilmiştir ${ }^{29}$. Ancak bununla birlikte yönetim kurulu üyelerinin üçüncü kişilere ait payları temsilen genel kurulda oy kullanma hakkına sahip olup olmadığı hususu kanun koyucu tarafından açıklığa kavuşturulmamıştır. Bu gibi durumlarda da yönetim kurulunun, diğer pay sahiplerine ait oy haklarını temsilen kullanması kanımızca mümkün değildir. Zira TTK md. 389 hükmünün amaçsal (gai) yorum metoduyla yorumlanması halinde, söz konusu hükmün amacının, yönetim kuruluna sermaye riskine dayanmayan oy gücü verilmesini önlemek olduğu açıkça anlaşılmaktadır ${ }^{30}$.

Oy haklarının donması sonucu genel kurulda temsil edilemeyen payların kanımızca toplantı nisabından da düşülmesi gerekir. Bir başka deyişle toplantı nisabı tespit edilirken, donmuş oylar hesaba katılmamalıdır. Zira donma hali, söz konusu payların -bir an / geçici bir süre için- yok sayılması manasına gelmektedir ve bu nedenle "donma" süresince bu payların nisaplara dahil edilmemesi gerekir. Aynı şekilde bağlı şirketin iktisap ettiği hakim şirket payları da hakim şirketin genel kurul toplantı nisabında hesaba katılmamalıdır. Bu durumda şirketin elinde bulundurduğu kendi payları, toplam pay miktarından düşülecek ve arta kalan miktar üzerinden toplantı nisabı tespit edilecektir. Aynı yöntemin benzer gerekçelerle karar nisabı için de uygulanacağı kabul edilmiştir ${ }^{31}$.

\footnotetext{
${ }^{22}$ ÖZDAMAR, s.219; TEOMAN, Şirketçe Devralınan Paylar, s.265.

${ }^{23}$ Toplantı nisapları tedavüldeki paylara göre hesaplanacaktır. Bu konu hakkında detaylı bilgi için bkz.: DOMANİÇ, Hayri: Anonim Şirketler Hukuku ve Uygulaması TTK Şerhi-II, 1.Bas1, Temel, 1988, s.586; İMREGÜN, Oğuz: Anonim Ortaklıklar, 1.Bası, Yasa, 1989, s.279.

${ }^{24}$ TEOMAN, Şirketçe Devralınan Paylar, s.262; TEKİNALP, Yeni Ortaklıklar, s.377. Bu kapsama pay bağlı tüm yönetsel hakların gireceği yönünde bkz.: ÖZDAMAR, s.218.

${ }^{25}$ ÇELIKTAŞ, s.147.

26 TEOMAN, Ömer, Anonim Ortaklıkta Pay Sahibinin Oydan Yoksunluğu, 1.Bası, Bankacılık Enstitüsü 1983, s.203; POROY, Reha/TEKINALP, Ünal/ÇAMOĞLU, Ersin: Ortaklıklar ve Kooperatif Hukuku, 12.Bası, Vedat, İstanbul 2010, s.439.

${ }^{27}$ POROY/TEKINALP/ÇAMOĞLU, s.382; PULAŞLI, Hasan: “Anonim Şirket Genel Kurul Kararlarının Sakatlığı ve Müeyyidesi”, Gazi Üniversitesi Hukuk Fakültesi Dergisi (Prof. Dr. Oğuz Kürşat Ünal'a Armağan), XVII (1-2), 2013, s.892; AYOĞLU, s.532.

${ }^{28}$ ÖZDAMAR, s.222; TEOMAN, Oydan Yoksunluk, s.273; AYDIN, s.284; ÇAPA, s.111. Bu durumda ilerde telafisi güç sonuçların doğmaması için, mahkemece TTK 449 hükmü gereğince, kararın yürütülmesinin durdurulmasına da karar verilebilecektir. MOROĞLU, Erdoğan: 6102 Sayılı Türk Ticaret Kanunu'na Göre Anonim Ortaklıkta Genel Kurul Kararlarının Hükümsüzlüğü, 6.Bası, On İki Levha, İstanbul 2012, s.276.

${ }^{29}$ ÜN, Şeyda Nur: 6102 Sayılı Türk Ticaret Kanunu'na Göre Anonim Şirketlerin Kendi Paylarını İktisabı (Yayımlanmamış Yüksek Lisans Tezi, Gazi Üniversitesi Sosyal Bilimler Enstitüsü, YÖK Tez Merkezi Tez No: 588388) 97; ÖZDAMAR, s.217.

30 TÜRK, s.297; TEOMAN, Oydan Yoksunluk, s.71. Paylara ait haklar donacağı için inançlı işlemle mülkiyetin devredilmesi de mümkün değildir. Bkz.: TEOMAN, Şirketçe Devralınan Paylar, s.265-266; ÇEKER, Mustafa: Anonim Ortaklıkta Oy Hakkı ve Kullanılması, 1.Bası, Bankacılık Enstitüsü 2000, s.211.

${ }^{31}$ Aynı yönde bkz.: TÜRK, s.290; ÇELİKTAŞ, s.216; ÖZDAMAR, s.220. Donan payların nisapların hesabında dikkate alınacağı yönünde bkz.: TEOMAN, Oydan Yoksunluk, s.178.
} 


\section{B. Malvarlıksal Haklarının Donması}

Anonim şirketin kendi paylarını iktisap ettiği durumlarda, iktisap edilen paylara ilişkin hazırlık devresi faiz hakkı ile kar payı ve tasfiye payı gibi tüm malvarlıksal haklar da donmaktadır. Malvarlıksal haklarının donması sebebiyle elde edilen kar şirket bünyesinde kalacaktır; ancak bu karın nasıl değerlendirileceği hususunda kanunda bir hüküm bulunmamaktadır ${ }^{32}$. Doktrinde ise bu konuda bir fikir birliğine varılamamıştır. Bir görüşe göre, donan paylara tekabül eden kar payları, şirketin yedek akçe hesabına aktarılmalıdır. Bu görüşe göre söz konusu kar payı artık serbest yedek akçe konumundadır ${ }^{33}$. $\mathrm{Bu}$ nedenle söz konusu kar payları şirketin malvarlığına dahil sayılmalıdır ${ }^{34}$. Ancak esas sözleşmeye eklenecek bir hükümle yahut genel kurul tarafidan alınacak bir kararla, söz konusu payların yedek akçeye ayrılmayarak, müstakbel pay sahibine (şirketin payları satacağı gelecekteki pay sahibine) ödenmek üzere ayrı bir hesapta bloke edilmesi de mümkündür ${ }^{35}$. Bir diğer görüşe göreyse, söz konusu kar payları gelecek yılın gelirleri arasına dahil edilmelidir ${ }^{36}$. Bu görüşe göre pay sahiplerinin anonim şirkete ortak olmalarındaki amaca da ulaşılmış olacaktı ${ }^{37}$. Bir diğer görüşe göreyse donan paylara tekabül eden kar payları, diğer (donmayan) pay sahiplerine, sermayeye katılım oranlarına göre dağıtılmalıdır. Bir başka deyişle şirketin kendi paylarını iktisap etmesi halinde, donmuş paya isabet eden kar paylarının şirket haricindeki diğer ortaklara dağıtılması gerekmektedir ${ }^{38}$. Son olarak esas sözleşmeye konulacak bir hüküm ya da genel kurulun alacağı bir kararla, söz konusu paylara ait kar payının dağıtım hesabına dahil edilmeyerek, dağıtılacak miktarın diğer pay sahiplerinin paylarına göre hesaplanması da mümkündür ${ }^{39}$. Kanımızca kar payının, söz konusu donan payların gelecekteki sahibine ödenmek üzere bloke edilmesi en ideal çözümdür. Zira burada bir "donma" hali söz konusudur ve şirket bu paylara geçici olarak sahip olmaktadır. Buradaki geçicilik hali, donan payların çözülmesi, bir başka deyişle satılması anına kadardır. Nasıl ki şirket ortaklarının kar payları diğer ortaklar arasında dağıtılamayacaktır, geçici süreyle donan ve şirketin yalnızca "emanetçi" konumunda olduğu bu paylara düşen kar paylarının da diğer ortaklar arasında dağıtılmaması ve tıpkı ortaklık payı gibi kar payının da "donarak" (bloke edilerek) payın satışına kadar muhafaza edilmesi gereklidir.

Şirketin tasfiye halinde olması durumunda, iktisap edilen paylardan dolayı tasfiye payı hakk1 bulunmamaktadır. Bu nedenle tasfiye payı, diğer pay sahiplerine dağıtılacaktır. Bir başka deyişle, tasfiye payı oranları belirlenirken, şirketin iktisap ettiği kendi payları hesaba katılmayacak, arta kalan tutar, diğer pay sahipleri arasında bölüştürülecektir ${ }^{40}$. Şirketin iktisap ettiği kendi paylarından doğan, malvarlığına ilişkin yeni pay alma hakkının da kullanılması mümkün değildir ${ }^{41}$.

Türk Ticaret Kanunu'nda karşılıklı iştirak, şirketler arasındaki hakimiyet ilişkisine göre farklı şekillerde düzenlenmiştir. Taraflar arasında hakimiyet ilişkisinin bulunmadığı durumlarda TTK md. 197 ve 201/1 uygulanırken, hakimiyet ilişkisinin bulunduğu durumlarda md. 201/2., 379/5., 389., $612 / 6$. ve $612 / 4$. hükümleri uygulanmaktadır ${ }^{42}$. Şirketler topluluğundaki bağll şirket vasıtasıyla pay iktisabı ile şirketin kendi paylarını doğrudan iktisabı aynı hükümlere tabiyken, malvarlıksal haklar açısından benzeri bir durum söz konusu değildir. Bu nedenle malvarlıksal haklar bakımından bir ayrıma gidilmiştir ${ }^{43}$. Bağlı şirketin, hakim şirketin paylarını iktisap etmesi durumunda, sadece oy hakkı ve bununla bağlantılı haklar donacağı için, malvarlığına ilişkin haklar kanımızca kullanılmaya devam edilebilecektir ${ }^{44}$. Bir başka deyişle, şirketler topluluğu hükümleri bakımından, şirketin kendi payını

\footnotetext{
${ }^{32}$ POROY/TEKINALP/ÇAMOĞLU, s.439; DOMANIÇ, s.586.

${ }^{33}$ POROY/TEKINALP/ÇAMOĞLU, s.439; AYOĞLU, s.543.

${ }^{34}$ von STEIGER, Fritz: İsviçrede Anonim Şirketler Hukuku (Çeviren:Tahir ÇAĞA), 1.Bası, Fakülteler Matbaası, İstanbul 1968, s.178; SEVI, Pay Devri, s.102.

${ }^{35}$ SEVİ, Pay Devri, s.102.

${ }^{36}$ DOMANIÇ, s.586; ÖZDAMAR, s.223; ÇAPA, s.113. Bu sayede şirketin karı artacak ve ekonomik açıdan büyüme gerçekleşecektir. ÇELIKTAŞ, s.210.

${ }^{37}$ ÇAPA, s.113. Bu sayede şirketin adeta başka bir şirketin paylarını iktisap etmesi ya da kaynaklarını başka bir yatırım aracına yönlendirmiş gibi olacağının kabul edileceği yönünde bkz.: ÇELİKTAŞ, s.210.

${ }^{38}$ TÜRK, s.298; AYDIN, s.286; OKUTAN NILSSON, Gül: Türk Ticaret Kanunu Tasarısı'na Göre Şirketler Topluluğu Hukuku, 1.Bas1, On İki Levha, İstanbul 2009, s.206.

${ }^{39}$ SEVI, Ali Murat: “Anonim Ortaklığın Kendi Payını Devralması Üzerine Bir İnceleme” BATİDER 22 (1), 2003, s.253254.

${ }^{40}$ TEOMAN, Ömer: "Limited Ortaklığın Edindiği Kendi Paylarından Doğan Hak ve Borçlar ve Edinmenin Diğer Bazı Sonuçları" in Otuz Y1l Ticaret Hukuku - Tüm Makalelerim - C.I:1971-1982, 1.Bası, İstanbul 2001, s.155; TÜRK, s.299. ${ }^{41}$ ÇAPA, s. $139 \mathrm{vd}$.

${ }^{42}$ Karşılıklı iştirak hususunda detaylı bilgi için bkz.: OKUTAN NILSSON, Gül: "Şirketler Topluluğunda Karşılıklı İştirak”, Marmara Üniversitesi Hukuk Fakültesi Hukuk Araştırmaları Dergisi, 18 (2), 2012, s.257 vd.

${ }^{43}$ ÇAPA, s.109; AYDIN, s.439. Mali hakların donmasının nasıl yorumlanması gerektiği hususunda detaylı bilgi için bkz:: OKUTAN NILSSON, Şirketler Topluluğu, s.203 vd.

${ }^{44}$ Aynı yönde: ÜN, s.100-101.
} 
iktisap etmesi, malvarlığına ilişkin hakların bağlı şirket tarafından kullanılmasına engel değildir. Diğer taraftan karşılıklı iştirak halinde malvarlıksal hakların da donması gerektiğini savunan yazarlar da mevcuttur ${ }^{45}$.

\section{Koruyucu İmkanlara İlişkin Hakların Donması}

Anonim şirkette pay sahibinin en önemli koruyucu imkanlarından birisi de genel kurul kararlarının iptalini dava edebilme hakkıdır. Kendi paylarını iktisap eden anonim şirketin, TTK md. 389 ve 446 hükümleri gereğince, iptal davası açma hakkı bulunmamaktadı4 ${ }^{46}$. Zaten bu imkan bulunsaydı dahi, söz konusu davanın açılması pratikte mümkün olmayacağı gibi bir fayda sağlaması da beklenmeyecekti. Zira davanın şirketin tüzel kişiliğine karş1 açıldığ 1 düşünüldüğünde, hem davalının hem de davacının şirketin bizzat kendisinin olması, bu davanın açılmasını olanaksız kıldığı gibi, bir an için açılmasının mümkün olduğunun kabulündeyse, davanın özenle takip edileceği hususunda ciddi şüpheleri de beraberinde getirecektir. Ayrıca bu durumda TTK md. 446 da yer alan dava şartının sağlanması da olanaklı görülmemektedir.

Pay sahiplerinin bir diğer koruyucu hakkı ise sorumluluk davası açma imkanıdır. TTK md. 553 hükmüne dayanan bu hakkın da TTK md. 389 hükmü gereğince kullanılması mümkün değildir. Tıpkı yukarıda izah edilen genel kurul kararın iptali davasında olduğu gibi, söz konusu davanın şirket tarafından kendi yönetim kuruluna veya yöneticilerine karşı açılması çok düşük bir ihtimaldir ${ }^{47}$.

\section{III. İKTISSAP EDILEN PAYLARIN DURUMU}

Anonim şirketin iktisap ettiği paylar, aşağıda izah edilen gerekli şartların oluşması halinde ya elden çıkarılır ya da itfa edilir. Elden çıkarma, payların şirketin pay sahiplerine ya da üçüncü kişilere devri anlamına gelirken; itfa, payın yok edilmesi demektir.

Anonim şirketin iktisap ettiği kendi paylarını süresiz olarak elinde tutması kural olarak mümkün değildir. Bu nedenle payın şirket tarafından elde tutulabileceği azami süreler de kanunda belirlenmiştir. TTK md. 379 hükmüne uygun iktisaplarsa, bu durumun istisnasını oluşturur ${ }^{48}$.

Şirketin paylarını elden çıkarırken eşit işlem ilkesine uygun hareket etmek ve şirkete borçlanma yasağına uygun davranmak zorundadır. Payların yok edilmesiyse kanunda belirtilen süreler içinde elden çıarılmayan payların sermaye azaltılması yoluyla gerçekleşecektir.

Aşağıdaki bölümde iktisabın kanuna uygun gerçekleşip gerçekleşmediği dikkate alınarak, payların elden çıkarılması ve yok edilmesi durumları ayrı ayrı incelenecektir.

\section{A. Payların Elden Çıkarılması Zorunluluğu}

1. Kanuna Uygun Olarak İktisap Edilen Paylar Bakımından

a. TTK md. 379 Hükmüne Uygun Olarak Gerçekleşen İktisap Bakımından

Anonim şirketin kendi paylarını TTK md. 379 hükmüne uygun olarak, esas veya çıkarılmış sermayenin \%10'unu aşmayan bir miktarda ve madde metninde geçen diğer şartlar altında iktisap etmesi durumunda, söz konusu payları belirli bir süre içinde elden çıkarma zorunluluğu bulunmamaktadır. Şirket gerekli gördüğü takdirde, herhangi bir sebebe dayanmaksızın, şartlara uygun olarak iktisap ettiği söz konusu payları, istediği müddetçe elinde tutabilmektedir. Bir başka deyişle şirket, söz konusu payları elden çıkarıp çıkarmama hususunda serbesttir ${ }^{49}$. Elden çıkarma zorunluluğu kanuna aykırı iktisaplar ve TTK md. 384 hülmü gereğince esas veya çıkarılmış sermayenin yüzde onunu aşan kısmı için söz konusudur ki, bu durum aşağıda ayrıca ele alınmışıır ${ }^{50}$.

TTK md. 379 gerekçesinde de belirtildiği üzere, payların elden çıkarılması zorunluluğunun bulunmamasının sebebi, bu yönde bir zorunluluğun düzenlenmemiş olmasıdır. Anonim şirketin kendi paylarını iktisap gereksinimi çeşitli nedenlerden doğabilmektedir ve söz konusu payların elde tutulması, şirketin ihtiyaçları giderilmedikçe veya bu gereksinim sebebi ortadan kalkmadıkça gerekli görülmektedir. Kanunun gerekçesinde de haklı olarak ifade edildiği gibi; şayet şirketin iktisap ettiği paylar için belirli bir süre içinde elden çıkarılma zorunluluğu getirilseydi, bu durumda yüzde on oranındaki koşulun da bir anlamı kalmayacakt1 ${ }^{51}$.

\footnotetext{
${ }^{45}$ AYOĞLU, s.534.

${ }^{46}$ Aynı yönde bkz.: TÜRK, s.303.

${ }^{47}$ TÜRK, s.303.

${ }^{48}$ TURAN, Gökçen: Anonim Ortaklıkların Kendi Paylarını İktisabının Genel Esasları, 1.Bası, Yetkin, Ankara 2018, s.45.

${ }^{49}$ COŞAR, Ayşe: “Anonim Şirketin “Kaçış Klozu” Vasıtasıyla Kendi Paylarını İktisap Ederken TTK m. 379'daki Yüzde Onluk Sınır ile Bağlı Olup Olmadığı Sorunu” Terazi Hukuk Dergisi, 15 (164), 2020, s.725.

${ }^{50}$ Bkz. Bölüm III-A-2.

${ }^{51}$ Türk Ticaret Kanunu Gerekçesi, md. 379 Gerekçesi, s.121.
} 
TTK md. 379 hükmüne uygun olarak iktisap edilen payların elden çıkarılması hususunda bir zorunluluk bulunmamakla birlikte, söz konusu payların şirket tarafından elden çıkarılması halinde, payların devrinin kanımızca eşit işlem ilkesine ve pay sahiplerinin şirkete borçlanma yasağına uygun bir şekilde gerçekleştirilmesi gerekir. Buna göre gerek payın satılacağı şirket ortaklarının belilenmesinde gerekse söz konusu payların fiyatlarının belirlenmesinde, yönetim kurulu TTK md. 357 hükmüne uygun işlem yapmakla mükelleftir ${ }^{52}$. Aksi takdirde söz konusu yönetim kurulu kararı, TTK md. 391 hükmü gereğince batıl olacaktır ${ }^{53}$.

TTK md. 379 hükmüne uygun olarak gerçekleştirilen her iktisap, kanuna uygun ve sorumluluğu ortadan kaldıran bir işlem olarak değerlendirilmemelidir. Zira herhangi bir zorunluluk bulunmamasına ve şirketin kendi paylarını kanuni sınırlar içerisinde iktisap etmesine rağmen, yönetim kurulu üyelerinin sorumluluğu doğabilmektedir. Örneğin şirketin malvarlı̆̆ının, kendi paylarını iktisap etmek yerine daha verimli bir kaynağa aktarılması, bununla önemli gelirler elde edilebilecek yatırımlar yapılması ve şirketin karlılığının arttırılması imkanları bulunurken, kaynağın şirketin kendi paylarını iktisabı için aktarılması, yönetim kurulu üyelerinin -kusuru varsa- TTK md. 369 ve 553 kapsamında sorumluluğunu da doğuracaktır ${ }^{54}$.

\section{b. TTK md. 382 ve 383 Hükümlerine Uygun Olarak Gerçekleşen İktisap Bakımından}

Türk Ticaret Kanunu'nun elden çıkarma başlıklı 384.maddesine göre, TTK md. 382 (b) ilâ (d) bentleri ve 383 hükümlerine göre iktisap edilip, \%10 sınırını geçmeyenler payların, tıpkı TTK md. 379 de belirtilen kanuna uygun iktisaplar gibi, elden çıkarılma zorunluluğu bulunmamaktadır. Elden çıarma zorunluluğu, TTK md. 384 gerekçesinde "ihtiyaç varsa paylar elde tutulmall, aksi halde devredilmelidir." ilkesiyle açıklanmıştır. Buna göre bir zorunluluk hali söz konusuysa paylar elde tutulacak, ancak zorunluluk ortadan kalktığı anda söz konusu payların elden çıkarılması gerekecektir ${ }^{55}$. Zira anonim şirketin kendi payların TTK md. 379 de yer alan şartlara uymadan iktisap etmesi ve söz konusu payları daimi olarak elinde tutması, şirketin kendi paylarını iktisabıyla ilgili birtakım problemleri de beraberinde getirecektir ${ }^{56}$. Ayrıca zorunluluğun ortadan kalmasına rağmen payların elde tutulması, iktisaba özgü birtakım kurallar ve sınırlamalar getirilmesi amacına da ters düşecektir ${ }^{57}$.

TTK md. 382 hükümüne göre, küllî halefiyet kuralı gereği, bir kanuni satın alma yükümünden doğan ve bedellerinin tümü ödenmiş olmak şartıyla ve cebrî icradan, bir şirket alacağının tahsili amaciyla iktisap edilenler haricindeki paylar ile TTK 383.madde de yer alan ivazsiz iktisapların \%10'luk azami sınırını aşan miktardaki paylar, devirleri mümkün olduğu anda ve her halükarda iktisap tarihinden itibaren üç yıl içinde elden çıkarılmak zorundadır.

TTK 384.maddenin yollamasiyla başvurulan TTK 382.maddesinin diğer bentlerinin uygulanması kanımızca mümkün değildir. Zira TTK 382/1-a hükmünde yer alan sermayenin azaltılması amacıyla yapılan iktisaplar, iktisap edilen paylar sermaye azaltımı için itfa edileceğinden, elden çıkarılması mümkün olmayacaktır ${ }^{58}$. Kapsam dışındaki diğer bent (382/1-e) bakımından da elden çıkarılmanın mümkün olmadığını kanısındayız. Zira menkul kıymetler şirketinin iktisap ettiği paylar, şirket faaliyetinin bir sonucudur ve süreklilik arz etmesi bakımından zorunlu elden çıkarmaya uygun değildir ${ }^{59}$.

TTK 384.md hükmünde belirtilen payların iktisabında, TTK 379.md hükmüne uygun iktisap edilen paylarda olduğu gibi, elden çıkarma zorunluluğu yalnızca kanunda öngörülen \%10'luk kısmı aşan paylar için geçerlidir. Şayet şirketin yahut bir şirketler topluluğu söz konusuysa bağl1 şirketin, sahip oldukları toplam pay miktarı, şirketin esas veya çıarılmış sermayesinin \%10'undan fazlaysa,

${ }^{52}$ HONSELL, Heinrich/VOGT, Nedim Peter/WATTER, Rolf: Basler Kommentar zum Schweizerischen Privatrecht, 2.Bas1, Basel-Genf-Münih 2002, Art.659 N.7a; SEVİ, Pay Devri, s.106. Yazara göre payların gerçek değerlerinin çok altında bir fiyatla satılması ve satış için devralana finansal destek sağlanması halinde, işlemin TTK md. 380 hükmü kapsamında "kanuna karşı hile" olarak değerlendirilmesi de mümkündür. Aynı yönde bkz.: TAŞDELEN, Nihat: "6102 Sayılı Türk Ticaret Kanunu'nun Anonim Ortaklık Pay Devrine Getirdiği Sınırlamalar” Dokuz Eylül Üniversitesi Hukuk Fakültesi Dergisi (Prof. Dr. Hakan Pekcanıtez’e Armağan), 16 (Özel Sayı), 2014, s.3366-3367.

${ }^{53}$ AYAN, Özge: “Anonim Şirketin Genel Kurul Kararı ile Kendi Paylarını İktisap Etmesi veya Rehin Almasının Koşulları (TTK 379)” Gazi Üniversitesi Hukuk Fakültesi Dergisi, XVII (1-2), 2013, s.200; ÇAPA, s.91.

${ }^{54}$ ÇAPA, s.91-92.

55 Türk Ticaret Kanunu Gerekçesi, md. 384 Gerekçesi, s.123. Kanun koyucunun katı bir tutum yerine hoşgörülü davranarak, yönetim kuruluna mevcut ekonomik şartları dikkate alarak, uygun bir zaman dilimi içinde payları elden çıkarması zorunluluğu getirdiği yönünde bkz.: PULAŞLI, Şerh, s.1241.

${ }^{56}$ PULAŞLI, Șerh, s. 1241.

${ }^{57}$ ÇELİKTAŞ, s.206; ÇAPA, s.100-101.

${ }^{58}$ Söz konusu bende yer verilmemesinin bir eksiklik olmadığı, bu bent uyarında şirket tarafından iktisap edilen payların, sermaye azaltılması kapsamında itfa edileceği yönünde bkz.: COŞAR, s.726.

${ }^{59}$ Aynı yönde bkz.: TURAN, s.49; ÜN, s.103. 
söz konusu fazlalık elden çıkarılmalıdır. Şirketin sahip olduğu ve \%10'u geçmeyen kısım ise elden çıarılmak zorunda değildir.

TTK 384.md hükmü ivazsız iktisap edilen paylar yönünden de geçerlidir ve bu iktisaplar bakımından, payların şirketi kayba uğratmayacak şekilde devirleri mümkün olur olmaz ve her halükarda azami üç yıllık sürede elden çıkarılması gerekecektir ${ }^{60}$. Süre, payların iktisap edildiği tarihten itibaren başlayacaktır. Kanunda belirtilen süre zarfında payların devredilmemesi TTK 384.md hükmünü ihlal ederken; söz konusu süre zarfında en uygun zamanda payların devredilmemesi ve üç yıllık sürenin sonuna kadar beklenmesi ise kanımızca TTK 369.md hükmünün ihlal edildiği anlamına gelebilecektir. En uygun zamanın tespiti ise TTK 369.md hükmü gereğince özen ve bağlllık yükümlülüğü kıstasları çerçevesinde belirlenecektir.

Payların devredilmesi halinde söz konusu paylar elden çıkarılmadan önce, genel kuruldan bir karar alınmasına gerek yoktur. Zira yönetim kurulu bu yetkiyi, kanundan almaktadır ${ }^{61}$. Yönetim kurulunun bu husustaki tek yükümlülüğü, eşit işlem ilkesine ${ }^{62}$ ve özen yükümlülüğüne uygun hareket etmektir ${ }^{63}$.

\section{Kanuna Aykırı İktisap Edilen Paylar Bakımından}

\section{a. Payın Durumu}

Genel kuruldan yetki alınmadan, bedeli tamamen ödenmeden ya da bedelleri bağgl malvarlığından karşılanarak iktisap edilen paylar ile TTK 379.md hükmüne uygun iktisap edilip de \%10'luk sınırı aşan paylar, kanuna aykırı iktisap olarak değerlendirilmektedir. Yakın ve ciddi bir kayıp tehlikesi söz konusu olmamasına ve genel kurulun herhangi bir yetkilendirmede bulunmamasina rağmen, yönetim kurulunun alacağı bir kararla şirketin kendi paylarını iktisabı da bu kapsamda değerlendirilecektir ${ }^{64}$. Aynı şekilde şirketin payını üçüncü kişiye devrederken, işlem için devralana finansal destek vermesi ya da inançlı devir işlemlerinde payın devri hukuka aykırıdır ve söz konusu işlem geçersizdir ${ }^{65}$.

Türk Ticaret Kanunu'nun aykırı iktisap hâlinde elden çıkarma başlıklı 385.maddesine göre; TTK 379. ve TTK 381.md hükümlerine aykırı olarak iktisap edilen bu paylar, iktisap tarihinden itibaren en geç altı ay içinde elden çıkarılmalıdır ${ }^{66}$.

TTK 385.md hükmünde "379 ilâ 381 inci maddelere" ifadesiyle, TTK 380.maddenin de bu kapsama gireceği düşünülebilse de söz konusu madde kanuna karşı hile kurallarını düzenlediği için, madde hükmü gereğince finansal destek sağlamaya yönelik işlemlerle dolaylı temsil yoluyla iktisaplar geçersiz sayılmıştır. Bu durumda destek sağlayıcı işlem geçersiz, iktisap işlemi ise geçerli kabul edilecektir. Bu nedenle 380.maddenin bu kapsamda değerlendirilmesi kanımızca mümkün değildir. Bir başka deyişle finansal destek sonucu üçüncü kişinin elinde bulunan paylar bakımından söz konusu payların altı ay içinde elden çıkarılması zorunluluğu bulunmamaktadır ${ }^{67}$. Altı ay içinde elden çıkarılmayan paylar ise, TTK 386.md hükmü gereğince, sermayenin azaltılması yoluyla itfa edilecektir.

TTK 384.md hükmü gereğince, TTK 382 ve 383.maddelere uygun şekilde iktisap edilip, \%10'luk sınırı da aşmayan paylar bakımından da elden çıkarılma zorunluluğu bulunmamaktadır. Ancak söz konusu paylar \%10 sınırını aşmasa bile, diğer şartları taşımıyorsa, bu iktisabın da kanuna aykırı olduğu ve TTK 385 .md hükmü gereğince altı ay içinde elden çıkarılması gerektiğini belirtmek

\footnotetext{
60 ÜN, s.103-104.

${ }^{61}$ ÖZDAMAR, s.213.

${ }^{62}$ TEOMAN, Oydan Yoksunluk, s.78; ÖZDAMAR, s.214; AYDIN, s.267 vd. Aksi yönde ve herhangi bir gerekçe ileri sürmeksizin bkz.: POROY/TEKİNALP/ÇAMOĞLU, s.439. Eşit işlem ilkesinin uygulanmama sebebinin eTTK 329/II hükmü gereğince yönetim kuruluna şirketin sahip olduğu payları pay sahiplerine satma görevi değil, sadece payları en hızlı ve uygun şekilde elden çıkarma yetki ve görevi verildiği, bu nedenle yönetim kurulunun şirketin menfaatini dikkate alarak ve keyfilikten uzak davranarak elindeki payları istediği zaman satma imkanına sahip olduğu ve bu işlemin ortaksal alana ilişkin olmayacağı sebepleriyle aksi görüşün savunulması hakkında detaylı bilgi için bkz.: YILDIZ, s.82.

63 TEOMAN, Oydan Yoksunluk, s.78

${ }^{64}$ ÇAPA, s.96.

${ }^{65}$ SEVİ, Pay Devri, s.106. Yazara göre devir TTK md. 385 hükmü uyarında gerçekleşmekle birlikte söz konusu işlem TTK md. 380 hükmü uyarınca kesin hükümsüz sayılmalıdır.

${ }^{66}$ Pay sözcüğü hem senede bağlanmamış payı hem de pay senedini kapsamaktadır ve burada ifade edilen sözcüğün hangi manada kullanıldığı hususundaki tespit mahkeme kararıyla yapılabilmektedir. Bkz. Türk Ticaret Kanunu Gerekçesi, md. 385 Gerekçesi, s.123.

${ }^{67}$ ÜN, s.104-105; TURAN, s.s.47.
} 
gerekir $^{68}$. Aykırıllı̆ın tek sebebi sınırın aşılmasıysa, bu durumda elden çıkarma zorunluluğu yalnızca \%10'luk kısmı aşan miktar bakımından söz konusu olacaktır.

Kanuna aykırı iktisap edilen payların elden çıkarılması usulü ve payların hangi bedel üzerinden elden çıkarılacağı hususu kanunda düzenlenmemiştir. İdare işlevinin bir sonucu olarak söz konusu görev, yönetim kurulu tarafından yerine getirilecektir. Gerekçede de belirtiliği üzere, yönetim kurulunun bu görevini, özen yükümlügü çerçevesinde, eşitlik ve kamuyu aydınlatma ilkelerine uygun olarak yerine getirmesi gerektiği kanısındayız ${ }^{69}$. Bu noktada payın gerçek değeri altında satılmaması ve payı devralacak kişinin ise yönetim kurulu üyesi, pay sahibi, şirket çalışanı ya da ortaklıkla ilgisi olmayan bir kişi olması gerekir ${ }^{70}$.

\section{b. İşlemin Durumu}

Kanun koyucu, TTK 385.md hükmü gereğince kanuna aykırı iktisapları düzenlemekle birlikte, TTK 379.md hükmüne aykırı şekilde gerçekleşen iktisabın hukuki akıbetinin ne olacağını belirtmemiştir. TTK 379.md gerekçesinde ise bu hususun çözümünün doktrin ve yargı kararlarına bırakıldığ1 ifade edilmiştir ${ }^{71}$. Kanunun lafzında geçen "...iktisap edemez..." ifadesi bir yasaklama/engelleme olarak yorumlanabilse de hükmün gerekçesinde "işlemin geçersizliği" görüşünün yabancı doktrinde kabul edilmediğine işaret edilmiştir.

Türk doktrininde durum tartışmalıdır ${ }^{72}$. Bir görüşe göre; kanuna aykırı olarak gerçekleşen iktisap işlemi geçerlidir ve TTK 385.md hükmü uygulanmalıdır ${ }^{73}$. Aynı şekilde işlemin geçerli olduğunu savunan bir başka görüşe göre, TTK 379.md hükmüne aykırılık durumunun, sermayenin iadesi yasağına da aykırı olması halindeyse, iktisap işleminin geçersiz olacağ 1 ileri sürülmektedir ${ }^{74}$. Bir başka görüşe göreyse, TTK 379.md de yer alan kuralın emredici olması sebebiyle bu maddeye aykırılığın sonucunun hükümsüzlük olduğu belirtilmiştir ${ }^{75}$.

Alman Hukuku'na göre şirketin kendi paylarını iktisabı AktG §71 hükmüne aykırı olması halinde, söz konusu borçlandırıcı işlem batıldır ve edim ifa edilmeyecektir. Diğger taraftan geçersizlik, tasarruf işlemine sirayet etmeyecektir. Bir başka deyişle borçlandırıcı işlem geçersiz, tasarruf işlemi ise geçerli olacaktır ${ }^{76}$.

İsviçre Hukuku'nda şirketin kendi paylarını iktisabıyla ilgili hüküm düzen kuralı olarak kabul edildiği için işlem geçerli kabul edilmektedir ${ }^{77}$. Ancak tarafların ortak amacı şirketin kendi paylarını iktisabı hükümlerinin koruma amacını ihlal etmek ise bu durumda İsvBK m. 20 gereği işlem batıl kabul edilmektedir ${ }^{78}$.

Kanımızca şirketin kendi paylarını kanuna aykırı şekilde iktisabı batıl olarak değerlendirilmemelidir. Zira kanuna aykırı iktisap edilen paylar önce şirketin mülkiyetine geçmekte, ardından da altı ay içinde elden çıkarılmaktadır. Bir başka deyişle kanunkoyucu da söz konusu payların mülkiyetinin şirkete geçtiğini kabul etmektedir. Zira TTK 385.md düzenlemesiyle iktisap edilen payların, altı ay içinde elden çıkarılması hüküm altına alınmıştır. Butlan yaptırımının kabulü, işlem güvenliği ilkesini de zedelemektedir ${ }^{79}$. Bu noktada, tıpkı İsviçre Hukuku'nda olduğu gibi, iktisap

\section{TURAN, s.46}

${ }^{69}$ Türk Ticaret Kanunu Gerekçesi, md. 385 Gerekçesi, s.123. Kamuyu aydınlatma ve şeffaflık ilkeleri hakkında detaylı bilgi için bkz.: TEKINALP, Ünal: “Türk Ticaret Kanunu Tasarısının Kurumsal Yönetim Felsefesine Yaklaşımı” in Uğur Alacakaptan'a Armağan, 1.Bası, İstanbul 2008, s.637; PASLI, Ali: Anonim Ortaklık Kurumsal Yönetimi, 1.Bası, Çağa, İstanbul 2004, s.74; KARASU, Rauf: "6102 Sayili Türk Ticaret Kanunu İle Anonim Şirketlerde Kurumsal Yönetim ile İlgili Getirilen Yenilikler”, İnönü Üniversitesi Hukuk Fakültesi Dergisi, 4 (2), 2013, s.55 vd.

${ }^{70}$ SEVI, Pay Devri, s.105-106. Yazara göre payın gerçek değerinin altında sayılması halinde TTK md. 380 hükmü gereğince kesin hükümsüzlük hali söz konusudur.

${ }^{71}$ Türk Ticaret Kanunu Gerekçesi, md. 379 Gerekçesi, s. 120.

${ }^{72}$ Tartışmalar hakkında detaylı bilgi için bkz.: AYDIN, s.293 vd.

73 ŞENER, Oruç Hami: Teorik ve Uygulamalı Ortaklıklar Hukuku, 1.Bası, Seçkin, Ankara 2013, s.383-384; BİLGİLI, Fatih/DEMIRKAPI, Ertan, Şirketler Hukuku, 9.Bası, Dora, 2013, s.477.

${ }^{74}$ SEVİ, Pay Devri, s.104. Yazara göre şirketin kendi payını iktisabı sonucunda ödediği devir bedeli, şirketin sermayesinin karşılığını azaltıyorsa, işlemin TBK md. 27/1 hükmü uyarınca kesin hükümsüz sayılması TTK md. 480/2 hükmünün bir gereğidir.

${ }^{75}$ PULAȘLI, Şirketler Hukuku, § 27, N.53; BAHTIYAR, Mehmet: Ortaklıklar Hukuku, 7.Bası, Beta, İstanbul 2012, s.215; ERIŞ, Gönen: Gerekçeli-Açıklamalı-İçtihatlı 6335 Sayılı Kanunla Güncellenmiş Yeni TTK Hükümlerine Göre Ticari İşletme ve Şirketler, C.II, 1.Bası, Seçkin, Ankara 2013, s.2627.

${ }^{76}$ Oechsler in GOETTE, Wulf/HABERSACK, Mathias/KALSS, Susanne (ed), Münchener Kommentar zum Aktiengesetz, 5.Bas1, Münih 2019, § 71, N.369.

${ }_{77}$ BAUEN, Marc/BERNET, Robert, Schweizer Aktiengesellschaft: Aktienrecht, Fusionsrecht, Börsenrecht, Steuerrecht, Basel 2007, s.49.

${ }^{78}$ BÖCKLI, Peter: Schweizer Aktienrecht, Basel 2009, s.572.

${ }^{79}$ TEKINALP, Yeni Ortaklıklar, s.76 vd. 
işlemini önce kabul edip, ardından payların elden çıkarılmasını beklemek en isabetli çözüm olacaktır. Ancak kanuna aykırılığın işlemin her iki tarafınca da bilinmesi ve ortak amacın söz konusu hükümlerin ihlal edilmesinin olduğu durumlardaysa, işlemi batıl kabul etmek gerekecektir ${ }^{80}$.

\section{B. Payların Yok Edilmesi Zorunluluğu (İtfa)}

Anonim şirketin, kendi payını belirli sınırları aşan düzeyde iktisap etmesi halinde yapılacak ilk işlem, yukarıda da izah edildiği gibi söz konusu payların elden çıkarılmasıdır. TTK 384.md kapsamında üç yıllık ve TTK 385.md kapsamında altı aylık süreler içinde elden çıarılmayan paylar ise TTK 386.md hükmü gereğince, sermayenin azaltılması yoluyla yok (itfa) edilecektir. Anonim şirketin belirtilen süreler içinde elden çıkarmadığı payların tekrar devredilmesine engel olmak yahut bu payların başka amaçlarla kullanılmasına engel olmak için, söz konusu payların yönetim kurulu tarafından hemen yok edileceği hüküm altına alınmıştır ${ }^{81}$.

TTK 386.md hükmünde geçen "hemen" ifadesi, TTK 385.md gerekçesine yapılan yollamayla açılığa kavuşturulmuş ve söz konusu ifadenin "hiç vakit geçirmeden" anlamına geldiği belirtilmiştir. Gerekçede de açıkça ifade edildiği üzere, hemen sözcüğü "şirket için müsait olan bir zamanda" şeklinde yorumlanamayacaktır ${ }^{82}$. Söz konusu payları elden çıkarması için şirkete zaten belirli bir süre tanındığı için, bu süreler içerisinde elden çıkarılmayan payların yok edilmesi için kanımızca ikinci bir zaman verilmesi mümkün değildir. Bu durumda söz konusu payların derhal yok edilmesi gerekecektir.

Yönetim kurulunun itfa ettiği paylar sebebiyle şirket sermayesinde bir azalma meydana gelecektir. Azaltılan kısımı karşılayan miktarda yeni paylar çıkarılacak ve bu payların bedelleri tamamen ödenecekse, esas sözleşmenin değiştirilmesine de gerek kalmayacaktır ${ }^{83}$. Bu durumda yok edilecek payların değerine eşit miktarda yeni paylar çıkarılacak ve bu payların bedelleri tamamen yedek akçelerden ödenecekse, sözleşme değişikliği yapılmayacaktır. Bu halde yeni pay bedelleri şirketin yedek akçelerinden karşlanarak mevcut pay sahiplerine dağıtılabileceği gibi üçüncü kişilerin söz konusu paylar için sermaye taahhüdünde bulunması da mümkündür. Ancak bu durumda bedelin peşin ödenmesi gerekir (TTK 473/1). Aksi halde sermaye azaltımına ilişkin genel kurul kararı alınması gerekecektir ${ }^{84}$. Azaltılan kısmın yerine bedelleri tamamen ödenen yeni payların çıkarılmaması halindeyse, sermayenin azaltılması zarar sebebiyle bilançodaki eksiğgin kapatılması olmadığı için, kurucu sermayenin azaltılması gerekecektir. Bu durumda şirketin iktisap ettiği kendi paylarını yok etmek için yapacağı sermaye azaltımında, yönetim kurulunun tüm alacaklıları çağırması ve bu kişilerin haklarının ödenmesi yahut teminat altına alınması gerekecektir ${ }^{85}$.

Esas sermayenin azaltılması başlıklı TTK 473.maddenin 5.fikra hükmüne göre, sermaye azaltımıyla TTK 332.md de öngörülen asgari sermaye miktarının altına inilemeyecektir. Bir başka deyişle sermaye azaltımı, en fazla asgari sermaye miktarına kadar yapılabilecektir. Payların itfasıyla, sermayesi kanunda belirtilen asgari miktarın altına düşecek olan şirketin yönetim kurulunun, TTK 456 vd. maddeleri gereğince derhal sermaye artırımına giderek, sermayeyi en azından TTK 332.md de belirtilen asgari sermaye miktarlarına yükseltmesi gerekmektedir ${ }^{86}$.

Yönetim kurulunun iktisap ettiği kendi paylarını süresi içinde elinden çıkarmaması ve bu nedenle kanuni zorunluluk gereği söz konusu payların itfa olması halinde, ilgili yönetim kurulu üyelerinin kusurlarının bulunması şartıyla, sorumlulukları da doğacaktır. Zira özenli ve tedbirli davranmayıp şirketin zararına sebebiyet veren yönetim kurulu üyeleri, TTK 369.md ve TTK 553.md hükümleri gereğince doğan zarardan sorumludur. Benzer bir düzenleme Alman Hukuku'nda da bulunmaktadır. Süresi içinde gerekli işlemlerin yapılmaması halinde gerek hukuka aykırı olarak edinilen gerekse yasal sınırı aşan düzeyde alınan payların AktG § 237 hükmü kapsamında sermaye azaltımı yoluyla itfa edilmesi gerekmektedir. Bu duruma sebep olan (sürenin aşılmasına sebep olan) yönetim ve gözetim kurulu üyelerinin ise pay sahiplerinin uğradığı zararlardan ötürü AktG § 93/III, 116 ve 405 hükümleri gereğince sorumlulukları doğmaktadır.

\footnotetext{
${ }^{80}$ Aynı yönde bkz.: COŞAR, s.725.

${ }^{81}$ SEVI, Pay Devri, s.106-107. 6762 sayılı Eski Türk Ticaret Kanunu dönemine ilişkin benzer açıklamalar için bkz.: ÖZDAMAR, s.210-211; İMREGÜN, s.279.

${ }^{82}$ Türk Ticaret Kanunu Gerekçesi, md. 385 Gerekçesi, s.123.

${ }^{83}$ TEKINALP, Ünal/ÇAMOĞLU, Ersin: Açıklamalı, Notlu ve Karşılaştırmalı 6102 Sayılı Yeni Türk Ticaret Kanunu ve Ticari Mevzuat, 13.Bası, Vedat, İstanbul 2011, TTK md. 473 notu, 227.

${ }^{84}$ SEVİ, Pay Devri, s. 107.

${ }^{85}$ SEVİ, Pay Devri, s.107.

${ }^{86}$ SEVİ, Pay Devri, s.107.
} 


\section{KAÇIŞ KLOZU İLE ŞİRKETİN KENDİ PAYLARINI İKTİSABI}

\section{A. Genel Olarak Kaçış Klozu}

Anonim şirket pay sahipleri, kural olarak sahip oldukları payları özgürce devretme imkanına sahiptir. Şirketin işleyişiyle ve kurum kültürüyle bağdaşmayan bir ortağın şirkete katılmasıysa, esas sözleşmedeki önemli sebeplerden birine dayanarak engellenemiyorsa, anonim şirket tarafindan TTK 493/1 hükmüyle engellenebilmektir. Söz konusu hükme göre, paylarını devreden ortağa, paylarının gerçek değerini öneren şirket, onay istemini reddedebilecektir. Kanun koyucu tarafindan "kaçış klozu" ${ }^{87}$ olarak adlandırılan bu müesseseyle, bir yandan ortaklar kendi paylarını gerçek değeri üzerinden satıp şirketten ayrilabilecekken, diğer taraftan pay sahibi olması istenilmeyen kişilerin şirkete ortak olmas1 engellenebilecektir ${ }^{88}$.

Kaçış klozunun kullanılabilmesi için devre konu payların borsaya kote edilmemiş bağlı nama yazılı paylardan olması ve şirketçe satın alma teklifinde bulunulması gerekir ${ }^{89}$. Ayrıca esas sözleşmede pay devri sınırlamasına yönelik bir bağlamın da bulunması gereklidir ${ }^{90}$. Esas sözleşmeyle devri sınırlandırılmayan nama yazılı paylar ise şirketin onayına ihtiyaç duyulmaksızın devredilebilecektir. Zira kaçış klozu, bağlı nama yazılı olmayan payların devrinde bir ret sebebi olarak öngörülmemiştir ${ }^{91}$. Bu yeni düzenleme, 6762 sayılı TTK dönemindeki "sebep gösterilmeksizin red" müessesesinin yeni, adil ve modern bir biçimidirr2 ${ }^{22}$

\section{B. Hukukuki Sonuçları}

Kaçış klozunun kullanılması halinde, istenmeyen üçüncü kişilerin şirkete ortak olması engellenerek, mevcut pay sahiplerinin payları, gerçek değeri üzerinden satın alınmaktadır. Şirketin, pay sahipleri ya da üçüncü kişiler adına pay iktisabı gerçekleştirmesi halinde TTK 379 vd hükümleri uygulama alanı bulamazken, kaçış klozu ile şirketin kendi paylarını iktisabı halindeyse, TTK 379 vd hükümlerinin uygulanıp uygulanmayacağı sorununu da gündeme gelmektedir ${ }^{93}$.

Türk doktrinindeki bir görüşe göre; TTK 493.md ile bir istisna getirildiğini ve şirketin satın alma hakkını tatbik ederken TTK 379 vd. maddeleriyle bağlı olmadığı ifade edilmiştir. Şirket kendi paylarını iktisap ederken, pay bedellerini serbest yedek akçelerden karşılamak zorunda da değildir. Ayrıca söz konusu paylar, TTK 384.md de belirtilen sürelere bağlı olmaksızın derhal elden çıarılmalıdır ${ }^{94}$.

Bir başka görüşe göreyse, şirketin kendi paylarını iktisap etmesi halinde, TTK 379 vd. hükümleri uygulanmalıdır. Bu bağlamda şirketin söz konusu pay bedellerini karşılayacak düzeyde serbest malvarlığı olmalıdır. Aksi takdirde işlem, emredici nitelikteki TTK 480/3.md hükmüne aykırı olacaktır ve bu aykırılık, işlemin geçersizliği sonucunu doğuracaktır. Bu görüşe göre, şirket TTK 379.md hükümünde belirtilen \%10'luk sınırı aşabilecektir; ancak söz konusu sınırı aşan kısım, TTK 385 ve 386.md hükümleri çerçevesinde 6 ay içinde elden çıkarılacak ya da sermaye azaltımı ile itfa edilecektir ${ }^{95}$.

\footnotetext{
${ }^{87}$ Uluslararası uygulama ve doktrinde "escape clause", "kaçış kolzu”, "kurtuluş klozu” olarak adlandırıldığı yönünde bkz.: Türk Ticaret Kanunu Gerekçesi, md. 493 Gerekçesi, s.180. İsviçre doktrininde de benzer kavramların kullanıldığı yönünde bkz.: FORSTMOSER/MEIER-HAYOZ/NOBEL, N.161, s.578. "Kaçış Klozu" yerine "satın alma önerisinde bulunma hakkı" kavramının kullanılması gerektiği yönünde bkz.: UZEL, Necdet: 6102 Sayılı Türk Ticaret Kanunu ve 6362 Sayılı Sermaye Piyasası Kanununa Göre Anonim Ortaklıkta Esas Sözleşmesel Bağlam, 1.Bası, On İki Levha, İstanbul 2013, s.303 vd.

${ }^{88}$ YÜKSEL, Sinan: "Borsaya Kote Edilmemiş Bağlı Nama Yazılı Payların Devrinde Şirketin Alım Önerisinde Bulunarak Onay İstemini Reddetme Hakkı (Kaçış Klozu)", Galatasaray Üniversitesi Hukuk Fakültesi Dergisi (Prof. Dr. Oğuz İmregün'e Sayg1 Sempozyumu), 2, 2013, s.168; BOZKURT, Tamer: Anonim Şirketlerde Pay Devrinin Sinırlandırılmas1 (Bağlam) -Die Vinkulierung-, 1.Bası, On İki Levha, İstanbul 2016, s.143. Kaçış klozunun pay devrini güçleştirdiğgi yönündeki eleştiriler için bkz.: ŞENER, s.620.

${ }^{89}$ YÜKSEL, s.167 vd; COŞAR, s.726-727.

${ }^{90}$ BİLGE, Kerem: Pay Sahipleri Sözleşmesi Kapsamında Anonim Şirketlerde Pay Devrinin Kısıtlanması, 1.Bası, On İki Levha, İstanbul 2017, s.87; YÜKSEL, s.167; UZEL, s.303 vd.

91 ALTAY, Sitkı Anlam Altay: "Türk ve İsviçre Anonim Ortaklıklar Hukuku'nda Esas Sözleşmesel Bağlam" in YASAMAN, Hamdi/ERDEM, Ercüment/DURAL, Ali/AYOĞLU, Tolga/ALTAY, Sitk1 Anlam/YUSUFOĞLU, Fülürya/YÜKSEL, Sinan (ed.), İsviçre Borçlar Kanunu'nun İktibasının 80. Y1lında İsviçre Borçlar Hukuku'nun Türk Ticaret Hukuku'na Etkileri, 1.Bası, Vedat, İstanbul 2009, s.602 vd.

92 BOZKURT, s.137.

${ }^{93}$ BILGE, s.95; BOZKURT, s.174.

${ }^{94}$ TEKINALP, Ünal: Anonim Ortaklıkta Yeni Bağlam Sisteminin Esasları, Pay Defteri Hukuku İle, 1.Bası, Vedat, İstanbul 2012, s.48; AYOĞLU, s.541 vd.

${ }^{95}$ KENDİGELEN, Abuzer: Anonim Ortaklık Payı Üzerinde İntifa Hakk1, 1.Bası, Beta 1994, s.607; SEVİ, Pay Devri, s.297.
} 
Diğer bir görüşe göreyse; kaçış klozuna ilişkin TTK 493.md hükmünün uygulanması esnasında, TTK 379.md de belirtilen sınırlara da uyulması gerekmektedir. Zira kaçış klozuna ilişkin düzenlemenin bir istisna olarak olarak kabul edilebilmesi için bu hususun kanunda açıça zikredilmesi gerekmektedir. $\mathrm{Bu}$ görüşe göre, bu şekildeki ağır bir istisna, yalnızca yorumlama metoduyla kabul edilemez, aksi takdirde şirket için uzun vadede riskler doğabilecektir. Diğer pay sahipleri ve üçüncü kişiler hesabına iktisabın mümkün olması sebebiyle, şirketin paylarını kendi adına iktisabı son çare olarak uygulanmalıdır ${ }^{96}$.

Bir diğer görüşe göreyse; TTK 379.md genel, TTK 493.md ise özel düzenlemedir ve özel düzenlemenin öncelikle uygulanması gerekir. Bu nedenle de şirketin kaçış klozundaki iktisabı, TTK 379.md de belirtilen \%10'luk sınıra tabi değildir. Şirket gerek kendi kaynaklarını gerekse dış kaynakları kullanabilecektir; ancak sınırsız bir serbesite içinde olmayacaktır ${ }^{97}$. Bu görüşe göre şirketin kendi paylarını iktisabı "kapalı devre" şeklinde uygulanmalı ve süreler "dürüstlük kuralı" çerçevesinde belirlenmelidir ${ }^{98}$.

Alman Hukuku'nda şirketin kendi paylarını iktisabı sınırlı hallerde kabul edilmiştir. Şirketin yakın ve ciddi bir zarar tehlikesi altında bulunması halinde, zararın önlenebilmesi için, şirketin kendi paylarını iktisap etmesi mümkündür. Örneğin şirketi kontrol edebilecek miktardaki hakim payların üçüncü kişilere devri, şirketin ticari çıkarları ve işleyişiyle bağdaşmayabilir. Dahası bu durum şirketi önemli miktarda zarar tehlikesiyle karşı karşıya bırakabilir. Bu durumda şirketin kendi paylarını iktsap etmesi mümkündür; ancak bu durumda şirket \%10'luk sınırlama dahilinde iktisap işlemini gerçekleştirecektir ${ }^{99}$.

İsviçre Hukuku'nda Art.659/I OR hükmüne göre, şirketin kendi paylarını iktsap etmesi halinde \%10'luk sınırın aşılmaması ve iktisabın serbest öz kaynaklardan karşılanması gerekmektedir. Art.659/II OR hükmüne göre, devir sınırlamasının gereği olarak satın alma gereçekleşiyorsa, iktisap edilen payların, şirket sermayesinin \%20'sini aşmaması ve bunun yarısının, bir başka deyişle \%10'luk kısmın, iki yıl içinde satılması gerekmektedir. Satış işlemi gerçekleştirilmediği takdirde, söz konusu paylar sermaye azaltımı yoluyla itfa edilecektir ${ }^{100}$.

Kanımızca bu durumda TTK 379.md de belirtilen \%10'luk sınıra bağlı olmak gerekmektedir. Zira şirketi herhangi bir yüzdesel sınıra tabi tutmamak, "kaçış klozu" ile kanun koyucunun iradesinden de "kaçmaya" çalışmak manasına gelecektir. Şöyle ki, kanun koyucu, şirketin kendi paylarını iktisabını sıkı şekil şartlarına tabi tutmuş ve bu yolla kendi paylarını iktisabını zorlaştırmaya çalışmıştır. Bir başka deyişle şirketin kendi paylarını iktisap edebilmesini istisnai bir durum olarak düzenlenmiştir. Dolayısıyla şirketin kaçış klozunu kullanarak sınırsız bir iktisap gerçekleştirebileceğini savunmak, kanun koyucunun amacıyla bağdaşmamaktadır.

Kaçış klozu ile sınırsız iktisabın gerçekleşebileceğini savunmak, sermayenin pay sahibine iadesi tehlikesini de beraberinde getirecektir. Bir başka deyişle, şirketin kendi paylarını iktisabı yoluyla şirket sermayesi, pay sahiplerine "adeta" iade edilerek, şirket alacaklıkları zarara uğratılabilecektir" ${ }^{101}$. Elbette bu tehlike \%10'luk sınırın olduğu durumlarda da söz konusudur; ancak bahse konu sınır, sermayenin iadesi yasağını ve alacaklıların uğrayabileceği muhtemel zararları da en aza indirmektedir. Öte yandan kanun koyucu TTK 493.md gerekçesinde ${ }^{102}$, TTK 379 ve 381 .maddeler arasında bir bağlantı kurmuş ve bu yolla \%10'luk sınırın kaçış klozunda da uygulanabileceği yönündeki iradesini ortaya koymuştur.

Şirketin kaçış klozu ile kendi paylarını iktisabına herhangi bir sınırlama getirmemek, şirketin yönetimine de dolaylı olarak müdahale edilmesi anlamına gelecektir. Şirket, iktisap ettiği kendi

\footnotetext{
${ }^{96}$ BOZKURT, s.168 vd.

${ }^{97}$ AKIN, Murat Yusuf: Anonim Ortaklıkta Bağl1 Nama Yazılı Hisseler, 1.Bası, Vedat, İstanbul 2014, s.86 vd.

${ }^{98}$ AKIN, s.87.

${ }^{99}$ YILMAZ, Asuman: “Alman Hukuku'nda Anonim Ortaklığın Kendi Paylarını Devralması ve "KonTraG" ile Getirilen Değişiklikler”, İstanbul Üniversitesi Hukuk Fakültesi Mecmuası, LXIII (1-2), 2005, s.253 vd.

100 "I. Einschränkung des Erwerbs

1 Die Gesellschaft darf eigene Aktien nur dann erwerben, wenn frei verwendbares Eigenkapital in der Höhe der dafür nötigen Mittel vorhanden ist und der gesamte Nennwert dieser Aktien 10 Prozent des Aktienkapitals nicht übersteigt.

2 Werden im Zusammenhang mit einer Übertragbarkeitsbeschränkung Namenaktien erworben, so beträgt die Höchstgrenze 20 Prozent. Die über 10 Prozent des Aktienkapitals hinaus erworbenen eigenen Aktien sind innert zweier Jahre zu veräussern oder durch Kapitalherabsetzung zu vernichten."

101 TEKINALP, Ünal: “Anonim Ortaklıkta Sermayenin Korunması İlkesi” in Prof.Dr.Rona Serozan’a Armağan, C.II, 1.Bas1, On İki Levha, İstanbul 2010, s.1686 vd; ÇELİKTAŞ, s.142 vd.

102 “... Bu haldeki iktisabı 381 inci maddenin kapsamında kabul etmek veya 379 uncu ve devamı maddelerde öngörülenlere ek bir istisna olarak değerlendirmek de mümkündür...” Türk Ticaret Kanunu Gerekçesi, md. 493 Gerekçesi, s.179.
} 
paylarından doğan oy haklarını kullanamayacak olsa da bu durum oy dengelerinin bozulmasına ve dolaylı bir müdahalenin gerçekleşmesine sebebiyet verecektir ${ }^{103}$.

\section{YEDEK AKÇE AYIRMA ZORUNLULUĞU}

Anonim şirketin kendi paylarını iktisap etmesi halinde, TTK 520/1.md hükmü gereğince iktisap değerlerini karşılayan tutarda yedek akçe ayırması gerekir. Hükümde ifade edilen yedek akçeler, kanuni yedek akçedir. Bu nedenle ayrılması zorunludur. Söz konusu yedek akçeler ayrılmadan dağıtılan kar payları ise TTK 512.md hükmü gereğince iade edilmelidir ${ }^{104}$.

Yedek akçe ayırma zorunluluğu yalnızca şirketin kendi paylarını ivazlı olarak iktisap ettiği haller için söz konusudur. Bir başka deyişle ivazsız olarak iktisap edilen paylar sebebiyle yedek akçe ayrılması gerekmemektedir. Nitekim kanun koyucu da 520/1.md son cümlede, "iktisap değerlerini karşılayan tutarda..." ifadesiyle bu duruma vurgu yapmıştır.

Şirket iktisap ettiği payları elinden çıkarmadığı müddetçe, söz konusu paylar için ayrılmış yedek akçeleri de muhafaza etmek durumundadır. TTK 520/1. fikranın ikinci cümlesi gereğince söz konusu yedek akçelerin, iktisap edilen payların devri ya da itfasından sonra, iktisap değerini karşılayan tutarda çözülmesi mümkündür. Söz konusu paylar için yedek akçeler de iktisap tarihinde kurulacaktır ve ayrılacak yedek akçede iktisap değeri esas alınacaktır ${ }^{105}$. Yedek akçeler, şirketin serbest malvarlığından ayrilmalıdır ${ }^{106}$.

Yedek akçe ayrılması her ne kadar kanunen bir zorunluluk olsa da şirketin kendi paylarını iktisap edebilmesinin bir şartı değildir. Dolayısıyla yedek akçe ayrılmadan gerçekleşen bir pay iktisabı geçerli olmakla birlikte, bu durumda yönetim kurulu üyelerinin sorumluluğu doğacaktır ${ }^{107}$. Ayrıca bu durumda şirketin yeteri kadar kaynağı bulunmadığı halde işlemin yapılmış olması sebebiyle kanımızca sermayenin iadesi yasağının da uygulama alanı bulabileceğini söylemek mümkündür.

\section{VI. İKTİSAP EDÍLEN PAYLARIN BILANÇODAKI DURUMU}

Türk Ticaret Kanunu'nun iktisaba ilişkin hükümlerinde, anonim şirketin iktisap ettiği kendi paylarının bilançoda gösterilmesi gerektiği hususunda bir düzenleme bulunmamaktadır. Diğer taraftansa bilançoya ilişkin TTK $74 \mathrm{vd}$. hükümlerinde, şirketin malvarlığına giren tüm hususların bilançoya geçirilmesi zorunluluğu bulunmaktadır ${ }^{108}$.

Anonim şirketin iktisap ettiği kendi paylara, bilançoda aktifler arasında yer verilmeli, bunun karşıllğında ayrılan kanuni yedek akçeler ise pasifler kısmında gösterilmelidir. Paylar aktif hale getirilirken pasif tarafta yer verilen yedek akçeler, bilanço dengesini sağlayarak sermayenin korunması ilkesi müessesine hizmet edecek ve şirketin tasfiyesinde iktisap edilen payların değerince bir miktarın varlığı, köpük sermayenin olumsuz yanlarını da bertaraf edecektir ${ }^{109}$. Türkiye Muhasebe Standartları32 paragraf 33'e göreyse, iktisap edilen paylar aktifleștirilmeyecek özkaynaklardan düşülecektir ${ }^{110}$.

Şirketin bilançoya geçirme yükümlülüğüne aykırı davranması, hem bilançonun oylandığı genel kurul kararının sakatlığına hem de yönetim kurulu üyelerinin sorumluluğuna sebep olacaktır ${ }^{111}$.

\section{SONUÇ}

Anonim şirketlerin kendi paylarını iktisabı, kanun koyucu tarafindan istisnai olarak kabul edilen bir düzenlemedir. Nitekim kanun koyucu söz konusu müesseseye ilişkin önemli birtakım sınırlamalar ve koşullar öngörmüştür. Anonim şirket, iktisap ettiği kendi paylarından doğan hakları, paylar şirketin elinde bulunduğu müddetçe kullanamayacaktır. Bu durum yönetime ilişkin hakların yanı sıra, temsil hakkı, malvarlıksal haklar ve koruyucu imkanlara ilişkin hakların da donmasına sebebiyet verecektir.

\footnotetext{
${ }^{103}$ ÇELIKTTAŞ, s. 143 .

104 SEVİ, Pay Devri, s.87. Karşı yönde bkz.: AYAN, s.196.

${ }^{105}$ Türk Ticaret Kanunu Gerekçesi, md. 520 Gerekçesi, s.191.

106 TÜRK, s.281.

${ }^{107}$ Aynı yönde bkz.: TÜRK, s.280.

108 ÖZDAMAR, s.226; CAPA, s.105-106.

${ }^{109}$ POROY/TEKİNALP/ÇAMOĞLU, s.435.

110 "TMS 32 Finansal Araçlar: Sunum” Standardı 01/01/2005 tarihinden sonra başlayan hesap dönemlerinde uygulanmak üzere 15/01/2019 tarihli ve 30656 sayılı Resmi Gazete'de (Mükerrer) yayımlanmıștır. Paragraf 33: "İşletmenin, özkaynağına dayalı finansal araçlarını yeniden edinmesi durumunda, bu araçlar ("işletmenin geri satın alınan kendi hisseleri”) özkaynaktan düşülür. İşletmenin özkaynağına dayalı finansal araçlarının alışından, satışından, ihracından ya da iptalinden dolayı kar veya zarara herhangi bir kazanç ya da kayıp yansıtılmaz. Bunun gibi, işletmenin geri satın alınan kendi hisseleri, işletme tarafindan ya da konsolide edilmişşirketler grubunun diğer üyeleri tarafindan geri alınabilir ya da elde tutulabilir. Alınan ya da ödenen tutarlar doğrudan özkaynakta muhasebeleştirilir.”

${ }^{111}$ SEVI, Pay Devri, s.87.
} 
Şirketin kendi paylarını iktisabı, payların elden çıkarılması zorunluluğunu da beraberinde getirecektir. TTK md. 379, 382 ve 383 hükümleri kapsamında istisnai olarak elden çıkarma zorunluluğu bulunmasa da bu hükümlere uygun gereçekleştirilen her iktisap, kanuna uygun ve sorumluluğu ortadan kaldıran bir işlem olarak kabul edilmemelidir. Zira işlemlerin yapılması esnasında yönetim kurulunun, kusurlu işlemlerinden ötürü TTK md. 369 ve 553 hükümleri çerçevesinde sorumlulukları bulunmaktadır. Ayrıca TTK md. 384 gerekçesinde belirtildiği gibi zorunluluk halinin ortadan kalkması halinde, söz konusu payların da elden çıkarılması gerekecektir. TTK md. 384'ün atıfıyla başvurulan TTK md. 382'nin diğer bentlerinin uygulanması ise -çalışmamızda da detaylı olarak açıkladığımız üzere- kanımızca mümkün değildir.

Payların kanuna aykırı olarak iktisap edildiği durumlarda, hukuka aykırı bir devir söz konusudur. Genel kuruldan yetki alınmaması, pay bedelinin tamamen ödenmemesi veya bedelin serbest yedek akçeden karşılanması yahut \%10'luk sınırın aşılması, bu anlamda kanuna aykırı iktisaptır. Aynı şekilde yakın ve ciddi bir kayıp tehlikesinin bulunmamasına rağmen, yönetim kurulunun şirket paylarını iktisap etmesi, kanuna aykırı olacaktır. Kanuna aykııı iktisap edilen payların elden çıkarılmasına ilişkin usul ve payların satış bedeline ilişkin bir düzenleme bulunmadığ için, idare işlevinin bir sonucu olarak söz konusu görevin yönetim kurulu tarafindan yerine getirilmesi gerektiği ve yönetim kurulunun bu görevini özen yükümlülüğü, eşitlik ve kamuyu aydınlatma ilkelerine uygun şekilde yerine getirmesi gerektiği kanısındayız.

Kanuna aykırı iktisapların geçersiz olduğu kabul edilmekle birlikte buradaki geçersizliğin ne olacağı ise -çalışmamızda da belirttiğimiz üzere- doktrinde tartışmalıdır. Kanımızca kanuna aykırı şekilde gerçekleşen iktisap işlemi batıl olarak değerlendirilmemelidir. Zira kanuna aykırı paylar öncelikle şirketin mülkiyetine geçmekte, ardından altı aylık süre içinde elden çıkarılmaktadır. Kanun koyucu da söz konusu payların mülkiyetinin şirkete geçtiğini kabul etmektedir. Bu noktada butlan yaptırımını kabul etmek, işlem güvenliği ilkesini de zedeleyecektir. Kanımızca öncelikle iktisap işlemini kabul edip, ardından da payların elden çıkarılmasını beklemek en isabetli çözüm olacaktır.

Anonim şirketin kendi paylarını iktisap ederken \%10'luk sınırı aşması halinde yapılacak ilk işlem payın elden çıarılması olmakla birlikte, TTK md. 384 ve 385 kapsamında elden çıkarılmayan paylar ise sermayenin azaltılması yoluyla yok edilecektir. Bu durumda kanun koyucunun da ifade ettiği gibi, payların "hemen" yok edilmesi gerekmektedir. Söz konusu payların elden çıkarılması için şirkete belirli bir süre verildiği için, bu süreler içinde elden çıkarılmayan payların yok edilmesi için kanımızca ek bir süre verilmesi mümkün değildir.

Payların itfa edilmesi sebebiyle şirket sermayesi azaltılırken, kanunda belirtilen asgari sermaye miktarlarının altına inilmemesi gerekir. Böyle bir durumla karşılaşılması halinde, derhal sermaye artırımına gidilmesi ve en azından asgari sermaye miktarlarına kadar bir artırım gerçekleştirilmesi gerekmektedir. Şayet azaltılan kısımı karşılayacak miktarda yeni paylar çıkartılacak ve bu payların bedelleri tamamen ödenecekse, esas sözleşmenin değiştirilmesine de gerek kalmayacaktır.

TTK md. 493/I hükmü gereğince, "kaçış klozu" kullanılarak, şirketin kendi paylarını iktisap etmesi durumundaysa, sınırlamaya tabi olunup olunmadığ hususunda doktrinde bir fikir birliğine varılamamıştır. Bu noktada kanaatimiz, TTK md.379 de belirtilen \%10'luk sınırın, kaçış klozunda da uygulanması yönündedir. Zira aksinin savunulması, çalışmamızda da vurguladığımız üzere, birçok sorunu da beraberinde getirecektir.

Anonim şirketin, iktisap değerini karşılayan tutarda yedek akçe ayırması gerekecektir. Bu husus TTK md. 520/1 hükmü gereğince bir zorunluluktur; ancak bu durum yalnızca şirketin kendi paylarını ivazlı olarak iktisap ettiği haller için söz konusudur. Söz konusu yedek akçeler ayrılmadan bir kar payı dağıtımı yapılırsa, bahse konu kar paylarının TTK md. 512 hükmü gereğince iade edilmesi gerekecektir.

Son olarak şirketin kendi paylarını iktisap etmesi halinde, iktisap edilen payların bilançoda gösterilmesi gerekliliği hususunda Türk Ticaret Kanunu'nda bir düzenleme bulunmamaktadır. Bununla birlikte TTK md. 74 vd. hükümleri gereğince, şirketin malvarlığına ilişkin bütün hususlar bilançoya geçirileceği için, iktisap edilen paylara ve bunun karşılığında ayrılan yedek akçelere de bilançonun pasif kısmında yer verilmelidir. 
KAYNAKÇA

AKIN, Murat Yusuf: Anonim Ortaklıkta Bağlı Nama Yazılı Hisseler, 1.Bası, Vedat, İstanbul 2014.

ALTAY, Sitkı Anlam Altay: "Türk ve İsviçre Anonim Ortaklıklar Hukuku’nda Esas Sözleşmesel Bağlam” in YASAMAN, Hamdi/ERDEM, Ercüment/DURAL, Ali/AYOĞLU, Tolga/ALTAY, Sıtk1 Anlam/YUSUFOĞLU, Fülürya/YÜKSEL, Sinan (ed.), İsviçre Borçlar Kanunu'nun İktibasının 80.Yılında İsviçre Borçlar Hukuku'nun Türk Ticaret Hukuku'na Etkileri, 1.Bas1, Vedat, İstanbul 2009.

ANSAY, Tuğrul: Anonim Şirketler Hukuku, 6.Bası, İstanbul 1982.

AYAN, Özge: “Anonim Şirketin Genel Kurul Kararı ile Kendi Paylarını İktisap Etmesi veya Rehin Almasının Koşulları (TTK 379)" Gazi Üniversitesi Hukuk Fakültesi Dergisi, XVII (1-2), 2013, s.185228.

AYOĞLU, Tolga: “Anonim Ortaklıkların Kendi Paylarını İktisap Etmeleri ve Karşılıklı Katılmalar Meselesi” in İsviçre Borçlar Kanunu'nun İktibasının 80. Yılında İsviçre Borçlar Hukuku'nun Türk Ticaret Hukuku'na Etkileri, 1.Bası, Vedat, İstanbul 2009.

BAHTIYAR, Mehmet: Ortaklıklar Hukuku, 7.Bas1, Beta, İstanbul 2012.

BARTU, Nihat: “Anonim Şirketlerin Kendi Hisse Senetlerini Satın Almaları” İstanbul Barosu Dergisi 8, 1947, s.346-351.

BAUEN, Marc/BERNET, Robert: Schweizer Aktiengesellschaft: Aktienrecht, Fusionsrecht, Börsenrecht, Steuerrecht, Basel 2007.

BİLGE, Kerem: Pay Sahipleri Sözleşmesi Kapsamında Anonim Şirketlerde Pay Devrinin Kısıtlanması, 1.Bası, On İki Levha, İstanbul 2017.

BİLGİL̇̇, Fatih/DEMİKAPI, Ertan: Şirketler Hukuku, 9.Bası, Dora, 2013.

BOZKURT, Tamer: Anonim Şirketlerde Pay Devrinin Sınırlandırılması (Bağlam) -Die Vinkulierung-, 1.Bası, On İki Levha, İstanbul 2016.

BÖCKLI, Peter: Schweizer Aktienrecht, Basel 2009.

COŞAR, Ayşe: “Anonim Şirketin "Kaçış Klozu” Vasıtasıyla Kendi Paylarını İktisap Ederken TTK m. 379'daki Yüzde Onluk Sınır ile Bağlı Olup Olmadığı Sorunu” Terazi Hukuk Dergisi, 15 (164), 2020, s.720-731.

ÇAPA, Mehmet Sadık: Anonim ve Limited Şirketlerin Kendi Paylarını İktisap Etmesi, 1.Bası, On İki Levha, İstanbul 2013.

ÇEKER, Mustafa: Anonim Ortaklıkta Oy Hakkı ve Kullanılması, 1.Bası, Bankacılık Enstitüsü 2000.

ÇELİKTAŞ, İlyas: Anonim Ortaklığın Kendi Paylarını İktisabı, 1.Bası, Arıkan, Ankara 2006.

DOMANIÇ, Hayri: Anonim Şirketler Hukuku ve Uygulaması TTK Şerhi-II, 1.Bası, Temel, 1988.

ERİŞ, Gönen: Gerekçeli-Açılklamalı-İçtihatlı 6335 Sayılı Kanunla Güncellenmiş Yeni TTK Hükümlerine Göre Ticari İşletme ve Şirketler, C.II, 1.Bası, Seçkin, Ankara 2013.

FORSTMOSER, Peter/MEIER-HAYOZ, Arthur/NOBEL, Peter: Schweizerisches Aktienrecht, 1.Bas1, Stämpfli 1996.

GOETTE, Wulf/HABERSACK, Mathias/KALSS, Susanne (ed): Münchener Kommentar zum Aktiengesetz, 5.Bas1, Münih 2019. (Yazar, MüKo AktG).

GÖKÇE, Ziya: "Şirket Hisselerinin Devir Engelleri ve Hukuki Sonuçları”, Türkiye Noterler Birliği Hukuk Dergisi, 106, 2000, s.43-55.

HONSELL, Heinrich/VOGT, Nedim Peter/WATTER, Rolf: Basler Kommentar zum Schweizerischen Privatrecht, 2.Bası, Basel-Genf-Münih 2002.

HÜFFER, Uwe: Aktiengesetz, 14.Bası, Beck 2020.

İMREGÜN, Oğuz: Anonim Ortaklıklar, 1.Bası, Yasa, 1989.

KARASU, Rauf: "6102 Sayili Türk Ticaret Kanunu İle Anonim Şirketlerde Kurumsal Yönetim ile İlgili Getirilen Yenilikler”, İnönü Üniversitesi Hukuk Fakültesi Dergisi, 4 (2), 2013, s.33-60.

KENDİGELEN, Abuzer: Anonim Ortaklık Payı Üzerinde İntifa Hakkı, 1.Bası, Beta 1994.

MOROĞLU, Erdoğan: 6102 Sayılı Türk Ticaret Kanunu'na Göre Anonim Ortaklıkta Genel Kurul Kararlarının Hükümsüzlüğü, 6.Bası, On İki Levha, İstanbul 2012.

NOMER, Füsun: “Anonim Ortaklıkta Eşit Davranma (Eşit İşlem) İlkesi” in Prof.Dr.Oğuz İmregün’e Armağan, İstanbul 1998, s.469-490.

OKUTAN NILSSON, Gül: "Şirketler Topluluğunda Karşılıklı İştirak”, Marmara Üniversitesi Hukuk Fakültesi Hukuk Araştırmaları Dergisi, 18 (2), 2012, s.255-268. (Kısaca: Karşılıklı İştirak)

OKUTAN NILSSON, Gül: Türk Ticaret Kanunu Tasarısı'na Göre Şirketler Topluluğu Hukuku, 1.Bası, On İki Levha, İstanbul 2009. (Kısaca: Şirketler Topluluğu)

ÖZDAMAR, Mehmet: Anonim Ortaklıkların Kendi Paylarını İktisap Etmesi (TTK md. 329), 1.Bası, Yetkin, Ankara 2005.

PASLI, Ali: Anonim Ortaklık Kurumsal Yönetimi, 1.Bası, Çağa, İstanbul 2004.

POROY, Reha/TEKINALP, Ünal/ÇAMOĞLU, Ersin: Ortaklıklar ve Kooperatif Hukuku, 12.Bası, Vedat, İstanbul 2010.

PULAŞLI Hasan: Şirketler Hukuku Genel Esaslar, 6.Bası, Adalet, Ankara 2020. (Kısaca: Şirketler Hukuku). 
PULAŞLI, Hasan: “Anonim Şirket Genel Kurul Kararlarının Sakatlığı ve Müeyyidesi”, Gazi Üniversitesi Hukuk Fakültesi Dergisi (Prof. Dr. Oğuz Kürşat Ünal'a Armağan), XVII (1-2), 2013, s.885-898. (Kısaca: Armağan).

PULAŞLI, Hasan: 6102 Sayılı Türk Ticaret Kanununa Göre Şirketler Hukuku Şerhi, Cilt II, 1.Bası, Adalet, Ankara 2011. (Kısaca: Şerh)

SEVİ, Ali Murat: “Anonim Ortaklığın Kendi Payını Devralması Üzerine Bir İnceleme” BATIDER 22 (1), 2003. (Kısaca: BATIDER)

SEVI, Ali Murat: Anonim Ortaklıkta Payın Devri, 4.Bası, Seçkin, Ankara 2018. (Kısaca: Pay Devri)

ŞENER, Oruç Hami: Teorik ve Uygulamalı Ortaklıklar Hukuku, 1.Bası, Seçkin, Ankara 2013.

TAŞDELEN, Nihat: “6102 Sayılı Türk Ticaret Kanunu'nun Anonim Ortaklık Pay Devrine Getirdiği Sınırlamalar" Dokuz Eylül Üniversitesi Hukuk Fakültesi Dergisi (Prof. Dr. Hakan Pekcanıtez'e Armağan), 16 (Özel Sayı), 2014, s.3351-3387.

TEKİL, Fehiman: Anonim Şirketler Hukuku, 1.Bası, İstanbul 1993.

TEKİNALP, Ünal/ÇAMOĞLU, Ersin: Açıklamalı, Notlu ve Karşılaştırmalı 6102 Sayılı Yeni Türk Ticaret Kanunu ve Ticari Mevzuat, 13.Bası, Vedat, İstanbul 2011.

TEKİNALP, Ünal: “Anonim Ortaklıkta Sermayenin Korunması İlkesi” in Prof.Dr.Rona Serozan'a Armağan, C.II, 1.Bas1, On İki Levha, İstanbul 2010, s.1681-1701. (Kısaca: Armağan)

TEKİNALP, Ünal: “Türk Ticaret Kanunu Tasarısının Kurumsal Yönetim Felsefesine Yaklaşımı” in Uğur Alacakaptan’a Armağan, 1.Bas1, İstanbul 2008. (Kısaca: Alacakaptan Armağan1).

TEKİNALP, Ünal: Anonim Ortaklıkta Yeni Bağlam Sisteminin Esasları, Pay Defteri Hukuku İle, 1.Bası, Vedat, İstanbul 2012. (Kısaca: Yeni Bağlam).

TEKİNALP, Ünal: Yeni Anonim ve Limited Ortaklıklar Hukuku ile Tek Kişi Ortaklığının Esasları, 2.Bası, Vedat, İstanbul 2012. (Kısaca: Yeni Ortaklıklar).

TEOMAN, Ömer: Anonim Ortaklıkta Pay Sahibinin Oydan Yoksunluğu, 1.Bas1, Bankacılık Enstitüsü 1983. (Kisaca: Oydan Yoksunluk).

TEOMAN, Ömer: "Limited Ortaklığın Edindiği Kendi Paylarından Doğan Hak ve Borçlar ve Edinmenin Diğer Bazı Sonuçları” in Otuz Y1l Ticaret Hukuku - Tüm Makalelerim - C.I:1971-1982, 1.Bas1, İstanbul 2001, s.150-161. (Kısaca: Limited Ortaklığın Edindiği Kendi Payları).

TEOMAN, Ömer: "Şirketçe Devralınan Payların Umumi Heyette Temsili Caiz Değildir Kuralının (TK. m. 329, f. 3, c. 2) Anlamı", in Otuz Y1l Ticaret Hukuku - Tüm Makalelerim - C.I:1971-1982, 1.Bas1, İstanbul 2001, s.261-273. (Kısaca: Şirketçe Devralınan Paylar).

TURAN, Gökçen: Anonim Ortaklıkların Kendi Paylarını İktisabının Genel Esasları, 1.Bası, Yetkin, Ankara 2018.

TÜRK, Ahmet: Anonim Ortaklığın Kendi Paylarını Edinmesi, 1.Bası, Adalet, Ankara 2016.

UZEL, Necdet: 6102 Sayılı Türk Ticaret Kanunu ve 6362 Sayılı Sermaye Piyasası Kanununa Göre Anonim Ortaklıkta Esas Sözleşmesel Bağlam, 1.Bası, On İki Levha, İstanbul 2013.

von STEIGER, Fritz: İsviçrede Anonim Şirketler Hukuku (Çeviren:Tahir ÇAĞA), 1.Bası, Fakülteler Matbaası, İstanbul 1968.

YILDIZ, Şükrü: Anonim Ortaklıkta Pay Sahipleri Açısından Eşit İşlem İlkesi, 1.Bası, Seçkin, Ankara 2004.

YILMAZ, Asuman: “Avrupa Birliği Hukuku'nda Anonim Ortaklığın Kendi Paylarını Devralması” in Prof.Dr.Ergun Özsunay’a Armağan, 1.Bas1, Vedat, İstanbul 2004, s.27-48. (Kisaca: Armağan)

YILMAZ, Asuman: "Alman Hukuku'nda Anonim Ortaklı̆̆ın Kendi Paylarını Devralması ve "KonTraG" ile Getirilen Değişiklikler”, İstanbul Üniversitesi Hukuk Fakültesi Mecmuası, LXIII (1-2), 2005, s.239-290.

YÜKSEL, Sinan: "Borsaya Kote Edilmemiş Bağlı Nama Yazılı Payların Devrinde Şirketin Alım Önerisinde Bulunarak Onay İstemini Reddetme Hakkı (Kaçış Klozu)", Galatasaray Üniversitesi Hukuk Fakültesi Dergisi (Prof. Dr. Oğuz İmregün’e Saygı Sempozyumu), 2, 2013, s.159218. 